\title{
Free radical modelling studies during the UK TORCH Campaign in Summer 2003
}

\author{
K. M. Emmerson ${ }^{1, * *}$, N. Carslaw ${ }^{1}$, D. C. Carslaw ${ }^{2}$, J. D. Lee ${ }^{3}$, G. McFiggans ${ }^{4}$, W. J. Bloss ${ }^{5}$, T. Gravestock ${ }^{5}$, \\ D. E. Heard ${ }^{5}$, J. Hopkins ${ }^{5}$, T. Ingham ${ }^{5}$, M. J. Pilling ${ }^{5}$, S. C. Smith ${ }^{5}$, M. Jacob ${ }^{6, *}$, and P. S. Monks ${ }^{6}$ \\ ${ }^{1}$ Environment Department, University of York, York, YO10 5DD, UK \\ ${ }^{2}$ Institute for Transport Studies, University of Leeds, Leeds, LS2 9JT, UK \\ ${ }^{3}$ Department of Chemistry, University of York, York, YO10 5DD, UK \\ ${ }^{4}$ School of Earth, Atmospheric and Environmental Science, University of Manchester, Manchester, M60 1QD, UK \\ ${ }^{5}$ School of Chemistry, University of Leeds, Leeds, LS2 9JT, UK \\ ${ }^{6}$ Department of Chemistry, University of Leicester, Leicester, LE1 7RH, UK \\ *now at: IÖZ (Interdisciplinary Environmental Research Centre), TU Bergakademie Freiberg, Brennhausgasse 14, 09599 \\ Freiberg, Germany \\ ** now at: School of Earth and Environment, University of Leeds, LS2 9JT, UK
}

Received: 31 August 2006 - Published in Atmos. Chem. Phys. Discuss.: 18 October 2006

Revised: 19 December 2006 - Accepted: 20 December 2006 - Published: 12 January 2007

\begin{abstract}
The Tropospheric ORganic CHemistry experiment (TORCH) took place during the heatwave of summer 2003 at Writtle College, a site 2 miles west of Chelmsford in Essex and 25 miles north east of London. The experiment was one of the most highly instrumented to date. A combination of a large number of days of simultaneous, collocated measurements, a consequent wealth of model constraints and a highly detailed chemical mechanism, allowed the atmospheric chemistry of this site to be studied in detail. Between 25 July and 31 August, the concentrations of the hydroxyl radical and the hydroperoxy radical were measured using laser-induced fluorescence at low pressure and the sum of peroxy radicals was measured using the peroxy radical chemical amplifier technique. The concentrations of the radical species were predicted using a zero-dimensional box model based on the Master Chemical Mechanism version 3.1, which was constrained with the observed concentrations of relatively long-lived species. The model included a detailed parameterisation to account for heterogeneous loss of hydroperoxy radicals onto aerosol particles. Quantilequantile plots were used to assess the model performance in respect of the measured radical concentrations. On average, measured hydroxyl radical concentrations were overpredicted by $24 \%$. Modelled and measured hydroperoxy radical concentrations agreed very well, with the model overpredicting on average by only $7 \%$. The sum of peroxy radicals was under-predicted when compared with the respective measurements by $22 \%$. Initiation via $\mathrm{OH}$ was dominated
\end{abstract}

Correspondence to: N. Carslaw

(nc12@york.ac.uk) by the reactions of excited oxygen atoms with water, nitrous acid photolysis and the ozone reaction with alkene species. Photolysis of aldehyde species was the main route for initiation via $\mathrm{HO}_{2}$ and $\mathrm{RO}_{2}$. Termination, under all conditions, primarily involved reactions with $\mathrm{NO}_{\mathrm{x}}$ for $\mathrm{OH}$ and heterogeneous chemistry on aerosol surfaces for $\mathrm{HO}_{2}$. The $\mathrm{OH}$ chain length varied between 2 and 8 cycles, the longer chain lengths occurring before and after the most polluted part of the campaign. Peak local ozone production of $17 \mathrm{ppb} \mathrm{hr}^{-1}$ occurred on 3 and 5 August, signifying the importance of local chemical processes to ozone production on these days. On the whole, agreement between model and measured radicals is good, giving confidence that our understanding of atmospheres influenced by nearby urban sources is adequate.

\section{Introduction}

The hydroxyl radical $(\mathrm{OH})$ is an important species in the atmosphere, which can react with almost all other species, oxidising them eventually to carbon dioxide and water. $\mathrm{OH}$ has a short lifetime $(<1 \mathrm{~s}$ in the mid-latitude continental boundary layer) and so its concentration is not directly affected by transport. Rather, the budget of $\mathrm{OH}$ is controlled by local concentrations of ozone $\left(\mathrm{O}_{3}\right)$, water, sunlight, volatile organic compounds (VOCs), carbon monoxide (CO) and oxides of nitrogen $\left(\mathrm{NO}_{\mathrm{x}}\right)$.

In polluted, urban environments, high levels of anthropogenic VOCs cause $\mathrm{OH}$ to be rapidly cycled to hydroperoxy $\left(\mathrm{HO}_{2}\right)$ and organic peroxy $\left(\mathrm{RO}_{2}\right)$ radicals, which in turn can react with $\mathrm{NO}$ to reform $\mathrm{OH}$. The reaction of $\mathrm{HO}_{2}$ with $\mathrm{NO}$

Published by Copernicus GmbH on behalf of the European Geosciences Union. 
also forms $\mathrm{NO}_{2}$, which can be photolysed, leading to the creation of $\mathrm{O}_{3}$. A single $\mathrm{OH}$ radical can initiate the degradation of many molecules of trace gases leading to not only their eventual removal from the atmosphere but also the formation of tropospheric $\mathrm{O}_{3}$. Clearly the $\mathrm{OH}$ radical plays a pivotal role in photochemistry, and a complete understanding of the sources, sinks and cycling of $\mathrm{OH}$ is essential to understanding the chemistry of the atmosphere. For a more detailed review of radical chemistry in the boundary layer, the reader is referred to the review by Monks (2005).

Under clean conditions where $\mathrm{NO}_{\mathrm{x}}$ concentrations are low, initiation via $\mathrm{OH}$ tends to be dominated by the photolysis of $\mathrm{O}_{3}$ at wavelengths $\leq 340 \mathrm{~nm}$. This reaction may yield an excited state oxygen atom $\left(\mathrm{O}^{1} \mathrm{D}\right)$, which can react with ambient water vapour to form two $\mathrm{OH}$ radicals. In polluted atmospheres, other photolytic processes become significant. Nitrous acid (HONO) can increase in concentration during the night in the presence of high levels of $\mathrm{NO}_{2}$ (Kurtenbach et al., 2001). The HONO formed overnight can then be photolysed at wavelengths of light below $400 \mathrm{~nm}$ producing $\mathrm{OH}$ radicals at dawn. This reaction promotes radical initiation via $\mathrm{OH}$ in the early morning hours, when high solar zenith angles prevent short wavelength UV light from penetrating the lower troposphere and hence production of $\mathrm{OH}$ through photolysis of $\mathrm{O}_{3}$ is suppressed. In addition, the photolysis of formaldehyde ( $\mathrm{HCHO}$ ), can lead to the formation of two $\mathrm{HO}_{2}$ radicals: the photolysis of $\mathrm{HCHO}$ and other aldehydes occurs further into the visible region of the spectrum than that of ozone to produce $\mathrm{OH}$, so allowing these processes to become relatively more important at the ends of the day (Alicke et al., 2003).

$\mathrm{OH}, \mathrm{HO}_{2}$ and $\mathrm{RO}_{2}$ radicals also undergo propagation reactions. For instance, $\mathrm{OH}$ can react with $\mathrm{CO}$ or $\mathrm{O}_{3}$ to produce $\mathrm{HO}_{2}$, whilst its reactions with hydrocarbons lead to the formation of $\mathrm{RO}_{2}$. In the presence of $\mathrm{NO}, \mathrm{RO}_{2}$ radicals are converted into $\mathrm{HO}_{2}$, which can go on to react with $\mathrm{NO}$ (polluted atmospheres) or $\mathrm{O}_{3}$ (clean atmospheres) to reform $\mathrm{OH}$.

Termination reactions also vary depending on the level of pollution. In clean atmospheres, the main termination reactions for $\mathrm{HO}_{X}$ (sum of $\mathrm{OH}$ and $\mathrm{HO}_{2}$ ) and $\mathrm{RO}_{2}$ are the self and cross-reactions of peroxy and hydroperoxy radicals, whilst in polluted atmospheres, the reaction of $\mathrm{OH}$ with $\mathrm{NO}_{2}$ to form nitric acid, $\mathrm{HNO}_{3}$, tends to be the dominant termination route. Termination of $\mathrm{HO}_{2}$ radicals through aerosol loss has also been shown to be important in the clean marine boundary layer by Haggerstone et al. (2005).

This paper describes the use of a zero-dimensional photochemical box model to establish the sources and sinks for $\mathrm{OH}, \mathrm{HO}_{2}$ and $\mathrm{RO}_{2}$ during the recent UK NERC (Natural Environment Research Council) TORCH (Tropospheric Organic Chemistry Experiment) campaign in Writtle, southeast England. The model incorporates a detailed chemical mechanism (the Master Chemical Mechanism, MCM), which is essential to understand the complexities of radical processing in urban areas. This technique has been used frequently at remote marine boundary layer sites and in rural continental environments, where models constrained with observations of longer-lived species have been used to predict radical concentrations for comparison with measurements (Carslaw et al., 1999a, 1999b, 2001, 2002; Martinez et al., 2003; Konrad et al., 2003; Ren et al., 2003; Sommariva et al., 2004).

Polluted environments have also been studied. During BERLIOZ (Berliner Ozone Experiment) in July and August 1998, good agreement was obtained between modelled and measured $\mathrm{OH}$ at $\mathrm{NO}_{\mathrm{x}}$ concentrations greater than $5 \mathrm{ppb}$ for the 2 days studied, but modelled $\mathrm{OH}$ and $\mathrm{HO}_{2}$ was overestimated by 100 and $40 \%$ respectively at low $\mathrm{NO}_{\mathrm{x}}$ (Konrad et al., 2003). Modelled $\mathrm{RO}_{2}$ was in good agreement with the measurements over the full range of observed $\mathrm{NO}_{\mathrm{x}}$ concentrations. During the Los Angeles Free Radical Experiment in September 1993, $\mathrm{OH}$ and $\mathrm{HO}_{2}$ concentrations were overpredicted by $\sim 25-50 \%$ on average (George et al., 1999). The $\mathrm{PM}_{2.5}$ Technology Assessment and Characterisation Study (PMTACS) program was held in New York City in the summer of 2001, and the measured to modelled ratio was 1.1 for $\mathrm{OH}$, and 1.2 for $\mathrm{HO}_{2}$ (Ren et al., 2003). The model under estimation was attributed to a combination of a missing propagation route from $\mathrm{HO}_{2}$ to $\mathrm{OH}$ (Tan et al., 2001) and to missing initiation routes for $\mathrm{OH}$, although the chemical reaction scheme used in the model was highly simplified (the RACM (Stockwell et al., 1997) scheme was used which adopts a lumping technique). In winter 2004, the $\mathrm{OH}$ measured to modelled ratio was 1.2 , but $\mathrm{HO}_{2}$ was under-predicted by a factor of 6 (Ren et al., 2006). This under-prediction was conjectured to be a lack of $\mathrm{HO}_{X}$ production and/or propagation terms, which do not involve the production or loss of $\mathrm{OH}$.

Observed concentrations of $\mathrm{OH}$ and $\mathrm{HO}_{2}$ during the Southern Oxidants Study (SOS) in Nashville, Tennessee in midsummer 1999, were factors of 1.3 and 1.6 higher than modelled $\mathrm{OH}$ and $\mathrm{HO}_{2}$, respectively (Martinez et al., 2003). The authors speculated that an unknown $\mathrm{OH}$ production route, which occurred both day and night and was well correlated with $\mathrm{HO}_{2}, \mathrm{O}_{3}$ and $\mathrm{HCHO}$, could go some way to explaining the model under-prediction of $\mathrm{OH}$ and $\mathrm{HO}_{2}$. The Mexico City Metropolitan Area (MCMA) study during April 2003 showed that under very polluted conditions, modelled $\mathrm{OH}$ and $\mathrm{HO}_{2}$ were under-predicted at night and during the morning rush hour, but over-predicted by $30 \%$ at noon (Shirley et al., 2005).

The Pollution of the Urban Midlands Atmosphere (PUMA) campaign (Emmerson et al., 2005a,b; Harrison et al., 2006; Heard et al., 2004) took place in Birmingham city centre during summer 1999 and winter 2000. Whilst there was generally good agreement between the modelled and measured $\mathrm{OH}$ concentrations, the model tended to underpredict during daylight hours (between 11:00 and 15:00 h), with modelled to measured ratios of 0.6 and 0.5 for $\mathrm{OH}$ during summer and winter respectively. However, the average model under-predictions were greatly skewed by a few 
occasions where the measured values became very high with no obvious explanation (Emmerson et al., 2005a). Measurements of $\mathrm{HO}_{2}$ were over-predicted by the model by a factor of 2 during the day, although only a very simple parameterisation was used to treat loss of $\mathrm{HO}_{2}$ to aerosol surface. A rate of production analysis carried out to investigate key radical sources and sinks indicated that oxygenated VOCs could be important in urban atmospheres, both for radical initiation (through photolysis of carbonyls for instance) and also in terms of radical propagation from $\mathrm{OH}$ to $\mathrm{RO}_{2}$ (Emmerson et al., 2005b).

The TORCH campaign took place during July and August 2003, in the grounds of Writtle College in the southeast of England. Writtle is ideally placed to examine the chemical processes occurring within air parcels travelling from the continent and over London, situated as it is some 25 miles north east of London. During the campaign measurements were made of 52 gas-phase species as well as physical and chemical aerosol characteristics, meteorological parameters and various photolysis rates. In particular, following the identification of the potential role of oxygenated VOCs in processing radicals during the PUMA campaign (Emmerson et al., 2005b), measurements of several of these species were made including methanol, ethanol, propanol, acetone, formaldehyde, acetaldehyde, methyl vinyl ketone and methacrolein (Lee et al., 2006).

Southern England experienced a heat wave during August 2003 , with temperatures peaking at $38.5^{\circ} \mathrm{C}$ in Kent. A widespread, regional smog enveloped the southern UK, as well as northern parts of France, Germany and the Netherlands. During this period, over 2000 excess deaths occurred in England and Wales, with $\sim 800$ thought to be related to the high ozone and $\mathrm{PM}_{10}$ concentrations (Stedman, 2004).

One of the major objectives of the TORCH campaign was to compare measured radical concentrations with results from comprehensive chemical mechanisms. In this paper, the TORCH experiment has been used to provide a test of in situ chemistry in partially processed polluted air, by comparing measured hydroxyl $(\mathrm{OH})$, hydroperoxy $\left(\mathrm{HO}_{2}\right)$ and organic peroxy $\left(\mathrm{RO}_{2}\right)$ radical concentrations with those predicted by models constrained by a comprehensive experimental dataset of organic and inorganic species. In addition, a rate of production analysis (ROPA) has been used to study the $\sim 14,000$ reactions in the model, to identify which reactions and species are key for driving the radical chemistry.

\section{Experimental}

TORCH was a consortium project involving 8 UK universities (Aberystwyth, Bristol, Imperial, Leeds, Leicester, Manchester, UEA and York), and took place from 25 July to 31 August 2003. Simultaneous measurements were made of meteorological conditions, aerosol size distribution and composition, $\mathrm{OH}, \mathrm{HO}_{2}, \mathrm{HO}_{2}+\Sigma \mathrm{RO}_{2}$, non-methane hydrocar- bons (NMHC), O-VOCs, $\mathrm{CO}, \mathrm{NO}, \mathrm{NO}_{2}, \mathrm{H}_{2} \mathrm{O}, \mathrm{O}_{3}$ and the photolysis rates of acetaldehyde, acetone, hydrogen peroxide, formaldehyde, nitric acid, nitrous acid, $\mathrm{PAN}, \mathrm{NO}_{2}$ and ozone $\left(\rightarrow \mathrm{O}^{1} \mathrm{D}\right)$. A brief summary of the main measurements used to constrain or compare with the model follows.

The site at Writtle in Essex is surrounded by crop-based agriculture (sunflowers and grain), and the area in the immediate vicinity of the site is a meadow field normally used as an overflow car park for the college during term time. The college was not busy during the fieldwork. There were gaps in the measured data owing to instrument downtime ( $\mathrm{HO}_{X}$ measurements in particular between 6-18 August) and a power failure on 11 August. With the exception of the given dates, data coverage was very good, enabling modelling studies of the radicals to be undertaken for most of the period between 27 July and 30 August.

Ozone was measured on site using a UV absorption detector (Thermo Environmental Instruments, Model 49C). The estimated uncertainty in the $\mathrm{O}_{3}$ concentrations was $\pm 2 \mathrm{ppbV}$. $\mathrm{NO}$ was measured using a $\mathrm{NO} / \mathrm{O}_{3}$ chemiluminescence analyzer (Thermo Environmental Instruments, Model 42C trace level), with the instrument sequentially measuring $\mathrm{NO}$ and $\mathrm{NO}_{x}\left(\mathrm{NO}+\mathrm{NO}_{2}\right)$ by use of a heated Molybdenum converter. The detection limit for the instrument was approximately $0.1 \mathrm{ppbV}$ for $\mathrm{NO}$ and total $\mathrm{NO}_{x}$. Calibrations for $\mathrm{NO}$ and $\mathrm{NO}_{2}$ were carried out using a gas standard (Air Products) and a resulting uncertainty for $\mathrm{NO}$ and $\mathrm{NO}_{2}$ measurements was estimated to be $\pm 0.2 \mathrm{ppbV}$.

$\mathrm{C}_{2}-\mathrm{C}_{7}$ NMHCs and $\mathrm{C}_{2}-\mathrm{C}_{5}$ oxygenated volatile organic compounds (O-VOCs) including alcohols, aldehydes and ketones were measured using a two-column, gas chromatograph (GC) with flame-ionisation detector as described in detail by Hopkins et al. (2002) and in Lee et al. (2006). The entire analysis process took around 1 hour (including a 10-min sampling period), and was fully automated. Detection limits were between 1 and $10 \mathrm{pptV}$ for NMHCs and 10-40 pptV for O-VOCs.

Measurements of $\mathrm{OH}$ and $\mathrm{HO}_{2}$ radicals were made by the University of Leeds using on-resonance, low pressure laserinduced fluorescence (LIF) at $308 \mathrm{~nm}$, through the FAGE (Fluorescence Assay with Gas Expansion) technique (Heard and Pilling, 2003 and references therein). The instrument was based upon the design deployed in previous campaigns, most recently described in Smith et al. (2005). In brief, the Leeds FAGE system employs a solid-state, Nd:YAG pumped Ti:Sapphire laser to generate $308 \mathrm{~nm}$ radiation for LIF excitation (see Bloss et al. (2003) for a full description of the laser system) which is directed into two low pressure fluorescence cells using fibre optic cables. Thus, using two separate fluorescence cells it is possible to simultaneously detect $\mathrm{OH}$ and $\mathrm{HO}_{2}$ (the latter through chemical conversion to $\mathrm{OH}$ via addition of $\mathrm{NO}$ ), by collecting the resultant $\mathrm{OH}$ fluorescence, at $\sim 308 \mathrm{~nm}$, using gated photomultipliers. Calibrations were carried out daily during the campaign using the photolysis of water vapour at $185 \mathrm{~nm}$ coupled with $\mathrm{O}_{3}$ actinometry, with 
average daytime detection limits of $3.75 \times 10^{5}$ and $2.77 \times 10^{6}$ molecule $\mathrm{cm}^{-3}$ for $\mathrm{OH}$ and $\mathrm{HO}_{2}$ respectively. The accuracy in the reported measurements is determined by the calibration accuracy and is $22 \%$ and $25 \%$ respectively $(1 \sigma)$ for $\mathrm{OH}$ and $\mathrm{HO}_{2}$ (Smith et al., 2005). The precision of the instrument (quoted as a percentage) will depend upon the concentration measured, and is controlled by fluctuations in the background signal (solar and laser-induced). The standard deviation of the background signal was \pm 2.6 counts $\mathrm{s}^{-1}$, and hence for $(\mathrm{OH})=3 \times 10^{6}$ molecule $\mathrm{cm}^{-3}$, the precision is $20 \%$, giving a total uncertainty in quadrature of $30 \%$ (Smith et al., 2005). For $\left[\mathrm{HO}_{2}\right]=1 \times 10^{8}$ molecule $\mathrm{cm}^{-3}(4 \mathrm{pptv})$, the corresponding $1 \sigma$ uncertainty is $28 \%$ (Smith et al., 2005).

Measurements of peroxy radicals $\left(\mathrm{HO}_{2}+\Sigma \mathrm{RO}_{2}\right)$ were carried out using the PEroxy Radical Chemical Amplifier (PERCA) technique (Fleming et al., 2006). Briefly, the method relies upon the $\mathrm{HO}_{2}$ and $\mathrm{OH}$ radical-catalysed conversion of $\mathrm{NO}$ and $\mathrm{CO}$ into $\mathrm{CO}_{2}$ and $\mathrm{NO}_{2}$ respectively, through addition of $\mathrm{NO}$ and $\mathrm{CO}$ into the inlet region. Organic peroxy radicals are converted into $\mathrm{HO}_{2}$ in the presence of $\mathrm{NO}$ to produce $\mathrm{NO}_{2}$ with varying efficiencies. The yields of both $\mathrm{CO}_{2}$ and $\mathrm{NO}_{2}$ are equal to $\mathrm{CL} *\left(\left[\mathrm{RO}_{2}\right]+\left[\mathrm{HO}_{2}\right]+[\mathrm{OH}]\right)$, where $\mathrm{CL}$ is the chain length, i.e. the number of $\mathrm{HO}_{2} / \mathrm{OH}$ inter-conversion cycles that occur before radical termination. The yield of $\mathrm{NO}_{2}$ was measured using commercial LMA-3 detectors, which was converted into $\left[\mathrm{HO}_{2}+\Sigma \mathrm{RO}_{2}\right]$ using $\Delta\left[\mathrm{NO}_{2}\right] / \mathrm{CL}$. The detector signal consists of a small $\mathrm{NO}_{2}$ enhancement from peroxy radical conversion on a much larger signal from ambient $\mathrm{NO}_{2}$ and titration of ambient $\mathrm{O}_{3}$ by $\mathrm{NO}$ added in the inlets. The detectors were calibrated each day by plotting minute values of this background signal with ambient measurements of $\mathrm{NO}_{2}$ and $\mathrm{O}_{3}$ from commercial instruments (see earlier in this section), which were sampling air close to where the PERCA inlets were located. The chain length was calculated using a calibration source based upon the photolysis of $\mathrm{CH}_{3} \mathrm{I}$ at $253.7 \mathrm{~nm}$ to yield $\mathrm{CH}_{3} \mathrm{O}_{2}$ at varying concentrations (Clemitshaw et al., 1997). A humidity correction factor equation (using ambient humidity and inlet temperatures) was applied to all PERCA data following Salisbury et al., (2002). Raw data were captured at a frequency of $1 \mathrm{~Hz}$ and peroxy radical mixing ratios were derived on a 1 -min basis with a $1 \sigma$ error of $42 \%$ (Fleming et al., 2006).

The rates of photolysis of a variety of species were measured using a $2 \pi$ sr spectral radiometer. The spectral radiometer used an imaging spectrograph and a diode array detector to spectrally resolve sunlight in the range $285-710 \mathrm{~nm}$ and raw intensities were converted to actinic fluxes using primary irradiance standards (NIST) at $1 \mathrm{~nm}$ intervals. Photolysis frequencies were then calculated using these fluxes and tabulated absorption cross-sections and photodissociation quantum yields (Edwards and Monks, 2003; Monks et al., 2004).

\section{The Model}

The Master Chemical Mechanism version 3.1 (MCM, available online at (http://www.chem.leeds.ac.uk/Atmospheric/ $\mathrm{MCM} / \mathrm{mcmproj}$.html) contains near-explicit chemical degradation schemes for 135 primary emitted VOCs, based on the most important species in the UK National Atmospheric Emissions Inventory (Jenkin et al., 2003; Saunders et al., 2003), resulting in $\sim 14000$ reactions involving $\sim 5000$ molecular and free radical species. The MCM is a comprehensive mechanism treating each degradation step explicitly and as such, makes no simplifications through the use of lumping techniques or the adoption of surrogate species. The MCM is as closely linked as possible to laboratory measurements and theoretical studies on component elementary reactions and so is more directly linked to available experimental data than are lumped mechanisms. The rates of three body reactions within the MCM were updated following recent recommendations (IUPAC, 2005).

The TORCH model utilises measurements of longer-lived species and physical parameters (such as meteorological data and photolysis rates) as input constraints at 15-min intervals. Predicted concentrations of the short-lived radical species are then compared with measurements. There were measurements of 39 VOC species from the field campaign that are primary emitted species with degradation mechanisms available in the MCM. These included $13 \mathrm{C}_{2}-\mathrm{C}_{8}$ alkanes, 11 $\mathrm{C}_{2}-\mathrm{C}_{5}$ alkenes, 6 aromatic species, acetylene, 1-3-butadiene, isoprene, formaldehyde, acetaldehyde, methanol, ethanol, propanol and acetone. A further 74 primary emitted VOC species were introduced to the model via straight-line relationships with benzene, o-xylene and acetone, which were all measured. These relationships were derived by running a trajectory model containing the same MCM chemistry and driven by emissions suitable for polluted conditions, and using the output to derive relationships between benzene, oxylene and acetone and the unmeasured species (with $\mathrm{r}^{2}$ varying between 0.83 and 1). In addition, the model was constrained with measured values of $\mathrm{NO}_{\mathrm{x}}, \mathrm{O}_{3}, \mathrm{PAN}$ and $\mathrm{CO}$, as well as temperature and water vapour concentration.

Many of the important photolysis rates were determined experimentally during TORCH, as detailed in the previous section. The remaining photolysis rates in the model were evaluated using the 2-stream isentropic approach used by Hough (1988), which assumes clear sky, summertime conditions. A cloud attenuation factor (CAF) was derived to normalise the calculated photolysis rates, by comparing the measured $\mathrm{j}\left(\mathrm{O}^{1} \mathrm{D}\right)$ rate with the theoretical maximum calculated by the model for the specific latitude and time of year. The CAF was then used to correct the calculated photolysis coefficients.

Dry deposition rates were assigned to 1105 species and applied over the depth of the mixing layer, which varies in the model between $300 \mathrm{~m}$ at nighttime, increasing to $1300 \mathrm{~m}$ as the boundary layer collapses in the morning. The values 
were taken from Derwent (1996) for $\mathrm{HNO}_{3}\left(2 \mathrm{~cm} \mathrm{~s}^{-1}\right), \mathrm{NO}_{2}$ $\left(0.15 \mathrm{c} \mathrm{s}^{-1}\right)$, PAN $\left(0.2 \mathrm{~cm} \mathrm{~s}^{-1}\right.$, assumed the same for 216 PAN-type species), $\mathrm{O}_{3}\left(0.5 \mathrm{~cm} \mathrm{~s}^{-1}\right)$ and $\mathrm{SO}_{2}\left(0.5 \mathrm{~cm} \mathrm{~s}^{-1}\right)$ and from Brasseur et al. (1998) for methyl- and ethyl-nitrate $\left(1.1 \mathrm{~cm} \mathrm{~s}^{-1}\right.$, assumed the same for 286 organic nitrates), $\mathrm{HCHO}\left(0.33 \mathrm{~cm} \mathrm{~s}^{-1}\right.$ and assumed the same for 222 organic aldehydes $), \mathrm{H}_{2} \mathrm{O}_{2}\left(1.1 \mathrm{~cm} \mathrm{~s}^{-1}\right)$ and $\mathrm{CH}_{3} \mathrm{OOH}\left(0.55 \mathrm{~cm} \mathrm{~s}^{-1}\right.$ and assumed the same for 976 organic peroxides).

The concentrations are calculated using Facsimile for Windows software and averaged to $15 \mathrm{~min}$ to be consistent with the time interval of the input constraints, before being compared with the radical data. The model was run with the same input data for 4 consecutive days in order for the calculated radical concentrations to achieve steady state. The final $24 \mathrm{~h}$ of the model run were then used as the 'model day' for comparison with the measurements. Running the model for longer than 4 days made no appreciable difference $(<0.6 \%)$ to the predicted results.

Unlike in our previous work in urban areas (Emmerson et al., 2005a, 2005b), radical termination via $\mathrm{HO}_{2}$ onto aerosol surfaces has been calculated using measurements of aerosol size and number distributions (following Haggerstone et al., 2005), and takes into account diffusion of $\mathrm{HO}_{2}$ to the particle surface and interfacial mass transport. Using the appropriate aerosol measurements, heterogeneous loss of $\mathrm{HO}_{2}$ was treated using a rate coefficient, $\mathrm{k}_{t}$, integrated over all bin sizes of particles up to $768 \mathrm{~nm}(1)$ :

$k_{t}=\int_{0}^{\infty} \frac{d V(r)}{d r}\left(\frac{r^{2}}{3 D_{g}}+\frac{4 r}{3 \overline{\nu \gamma}}\right)^{-1} d r$

where $\mathrm{k}_{t}$ is the rate of loss of $\mathrm{HO}_{2}$ to the aerosol surface, $\mathrm{V}$ is the volume of aerosol, $r$ is the particle radius (in a particular size bin), $\mathrm{D}_{g}$ is the gas diffusivity constant, $\bar{v}$ is the mean molecular velocity and $\gamma$ is the accommodation coefficient for uptake of $\mathrm{HO}_{2}$ onto the aerosols. In the atmosphere, $\gamma$ is a function of the aerosol composition and radius: the composition of the aerosol surface is assumed to be homogeneous for the purposes of this parameterisation.

There are few measurements of the accommodation coefficient of $\mathrm{HO}_{2}$ : the limited measurements available suggest a value in the range from $0.01-0.8$, with a strong dependence on the surface characteristics and temperature (Haggerstone et al., 2005; Thornton and Abbat, 2005). Haggerstone et al. (2005) carried out a review of the available literature, and found that a value of 0.2 was most appropriate for conditions experienced during a clean air campaign in the marine boundary layer at Cape Grim in Tasmania. It has been suggested that the value of the accommodation coefficient for $\mathrm{HO}_{2}$ may approach unity in urban areas (Saylor, 1997). In this work we have somewhat arbitrarily assumed a value of 0.5 , somewhere in the middle of reported values. The model sensitivity to the range of values was tested and it was found that the $\mathrm{HO}_{2}$ concentrations decreased by $\sim 18 \%$ when $\gamma$ was changed from 0.02 to 1.0. These results stress the need for further laboratory based measurements of the accommodation coefficient for $\mathrm{HO}_{2}$ on a range of surfaces applicable to the urban and suburban atmosphere.

A heterogeneous production rate for HONO, as recommended by Kurtenbach et al. (2001) has been parameterised in the model. By considering the relationship with $\mathrm{NO}_{2}$ concentrations, Kurtenbach et al. (2001) derive $\mathrm{k}_{\mathrm{HONO}}$ to be $(2.9 \pm 1.8) \times 10^{-3} \mathrm{~m} \mathrm{~min}^{-1}$. This assumes that HONO is formed when $\mathrm{NO}_{2}$ reacts with $\mathrm{H}_{2} \mathrm{O}$ in the presence of an aerosol surface. This route, rather than a HONO source from the ground surface is appropriate because the FAGE measurement inlet (and hence the model box height) is $6-7 \mathrm{~m}$ from the ground.

As well as predicting radical concentrations, the model was used to carry out a rate of production analysis (ROPA). The first stage in the ROPA involved isolating all reactions that play a part in the initiation, propagation or termination of $\mathrm{OH}, \mathrm{HO}_{2}$ and $\mathrm{RO}_{2}$. The rates of the key reactions for $\mathrm{OH}$ (reaction with $\mathrm{SO}_{2}, \mathrm{NO}_{2}, \mathrm{NO}, \mathrm{H}_{2}, \mathrm{HO}_{2}, \mathrm{H}_{2} \mathrm{O}_{2}, \mathrm{O}_{3}, \mathrm{CO}$ and $\mathrm{HCHO}$ and production from $\mathrm{HNO}_{3}$, $\mathrm{HONO}$ and $\mathrm{H}_{2} \mathrm{O}_{2}$ photolysis along with the reaction of $\mathrm{O}\left({ }^{1} \mathrm{D}\right)$ with water) and for $\mathrm{HO}_{2}$ (reaction with $\mathrm{NO}, \mathrm{HO}_{2}, \mathrm{O}_{3}$ and loss on aerosol and production from formaldehyde photolysis) were considered individually, but the remaining reactions were grouped to aid interpretation. For instance, the reaction rate for the production of $\mathrm{HO}_{2}$ from the photolysis of $\mathrm{HCHO}$ was studied as an individual reaction, but the rate of $\mathrm{HO}_{2}$ production from the photolysis of all other aldehyde species was grouped. A complete list of the groupings is detailed in Emmerson et al. (2005b).

\section{Results and Discussion}

The aim of the TORCH experiment was to sample partially processed, recently polluted air coming from London. This situation occurred for the early part of the campaign (28 July - 3 August), when air parcels originated in the Atlantic, and then passed over the Southern U.K and London before reaching the site from a southerly/south-westerly direction. The air was also Atlantic in origin on the 4 and 5 of August, but passed over northern France and the North Sea before arriving at the site from an easterly direction. A hot, stagnant period dominated from the 6-10 August (the heatwave period), when a high pressure weather system presided over the UK and much of Western Europe. The high pressure system was associated with very low (westerly) wind speeds ( 0.5 $5 \mathrm{~ms}^{-1}$ ) and maximum daily temperatures of $26-37^{\circ} \mathrm{C}$. Concentrations of many species increased at this time (Lee et al., 2006), although $\mathrm{OH}$ and $\mathrm{HO}_{2}$ measurements were unavailable. From the 13-24 August, the air was Atlantic in origin, and passed over the UK (via the Midlands) before arriving at the site in a westerly/north-westerly direction. Finally, the end of the campaign was dominated by air masses of an Arctic origin, which travelled over the North Sea before arriving 


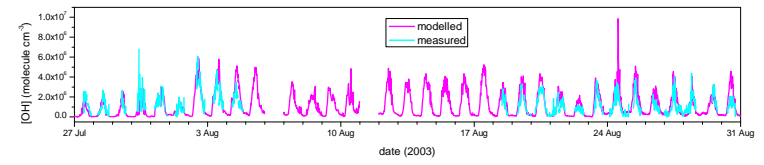

Fig. 1. Time series in modelled (magenta) and measured (cyan) $\mathrm{OH}$ concentrations during the TORCH 2003 campaign. Data are shown as 15-min averages for direct comparison. Measured data during the heatwave period are missing owing to technical problems.

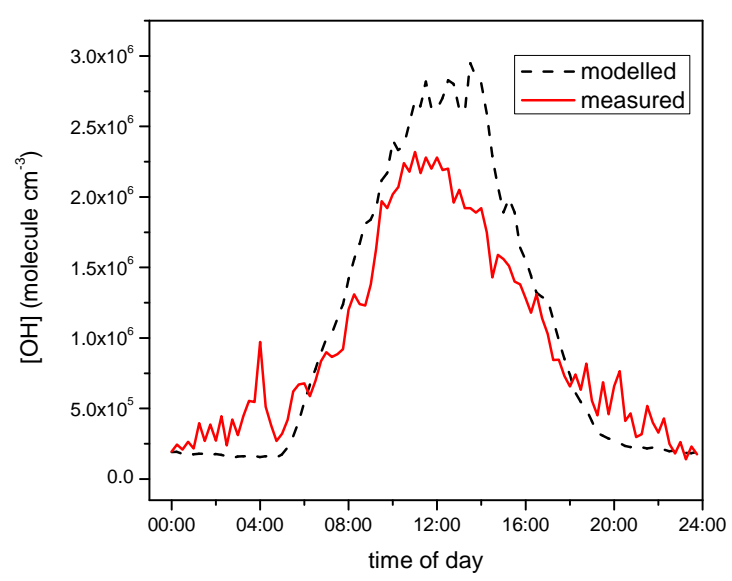

Fig. 2. 15-min average modelled and measured $\mathrm{OH}$ concentrations plotted as a diurnal time series. Modelled data are dashed black lines, measured data are red. (Number of data points contributing to the mean measured data varies between 20 and 85 ).

at Writtle from a northerly/north-easterly direction (see Lee et al. (2006) for more details). Thirty-two days of measurements were available to carry out modelling studies.

\subsection{The Hydroxyl Radical, $\mathrm{OH}$}

Measurements of $[\mathrm{OH}]$ show a diurnal cycle with daytime maxima between $1.2-7.5 \times 10^{6}$ molecule $\mathrm{cm}^{-3}$. There were six nights on which $[\mathrm{OH}]$ of up to $8.5 \times 10^{5}$ were measured (mean night-time detection limit $3.4 \times 10^{4}$ molecule $\mathrm{cm}^{-3}$, for a signal-to-noise ratio of 1 and an averaging period of $15 \mathrm{~min}$, with $5 \mathrm{~min}$ off-line to establish the background signal) indicative of significant night-time production of $\mathrm{OH}$. The nighttime data will be the subject of a future publication and will not be discussed further here. The average $[\mathrm{OH}]$ profile shows a rise that starts early in the morning $(\sim$ 05:00 $\mathrm{h})$ and persists into the evening $(\sim 18: 30 \mathrm{~h})$ when levels of $j\left(\mathrm{O}^{1} \mathrm{D}\right)$ are not significant. The 24 hour mean $[\mathrm{OH}]$ for the entire campaign (derived from hourly means) was found to be $1.4 \times 10^{6}$ molecule $\mathrm{cm}^{-3}$.

The time series of calculated and measured $\mathrm{OH}$ concen- trations are shown in Fig. 1 (note that all figures and times referred to in the text are in GMT). The agreement between modelled and measured $\mathrm{OH}$ concentrations is generally good. Between $27-29$ July, peak modelled and measured concentrations are $2.6 \times 10^{6}$ and $2.7 \times 10^{6}$ molecule $\mathrm{cm}^{-3}$, respectively. Agreement is also particularly good between 27-29 August where peak OH concentrations are $4.4 \times 10^{6}$ molecule $\mathrm{cm}^{-3}$ for both model and measurements. There are two dates on which there are significant departures in the agreement: 30 July where the measurements are a factor of 1.4 higher than the modelled $\mathrm{OH}$ concentrations between 11:00-15:00 h, and on 24 August, where the model over-predicts $\mathrm{OH}$ by a factor of 1.5 between 11:00-15:00 $\mathrm{h}$.

Figure 2 shows the modelled and measured $\mathrm{OH}$ data as two diurnal plots. Each $15 \mathrm{~min}$ period of the day has been averaged for all the days where there are model and measurement data available. Figure 2 shows that the greatest deviation between model and measurements occurs between $11: 00-16: 00 \mathrm{~h}$ and that agreement is generally better before and after this period.

The deviation between 11:00-16:00 $\mathrm{h}$ is interesting; these hours are certainly those of maximum chemical processing and indeed, concentrations of ozone remain high well into the afternoon. The model displays an asymmetric diurnal profile of $\mathrm{OH}$, whilst that of the measurements appears to be centred around solar noon. In terms of initiation via $\mathrm{OH}$, the reaction of $\mathrm{O}\left({ }^{1} \mathrm{D}\right)$ with water, the group of reactions of ozone with alkenes and monoterpenes and photolysis of HONO are of similar importance $\left(31,21\right.$ and $21 \times 10^{5}$ molecule $\mathrm{cm}^{-3}$ $\mathrm{s}^{-1}$ ) averaged over the period from 11:00-15:00 $\mathrm{h}$ for the whole campaign. With the exception of HONO photolysis, these initiation rates are based on measurements. Although the concentration of HONO is estimated by the model, its largest impact will be at dawn, when the overnight reservoir is rapidly photolysed. The agreement between modelled and measured $\mathrm{OH}$ is good at this stage, so the parameterisation adopted to calculate HONO concentration is unlikely to be the sole cause of the observed deviation.

The rate of production analyses are summarised in Table 1, which shows reaction rates for all initiation (radical product(s), no radical reactants), termination (radical reactant(s), no radical products) and propagation (radical to radical transformation) reactions of $\mathrm{OH}, \mathrm{HO}_{2}$ and $\mathrm{RO}_{2}$ for each day of the campaign between 11:00-15:00 $\mathrm{h}$ where measurements were available. Average concentrations of the key model input parameters $\mathrm{NO}_{\mathrm{x}}, \mathrm{O}_{3}, \mathrm{j}\left(\mathrm{O}^{1} \mathrm{D}\right)$ and $\mathrm{ppbC}$ (parts per billion of carbon in the form of VOCs) are also shown in Table 1 to aid interpretation of results. The $\mathrm{O}^{1} \mathrm{D}+\mathrm{H}_{2} \mathrm{O}$ route dominates initiation via $\mathrm{OH}(42 \%)$ on average, with the photolysis of $\mathrm{HONO}$ and $\mathrm{O}_{3}+$ alkenes both making up 29\%. During the heatwave period, $53 \%$ of initiation via $\mathrm{OH}$ occurred through $\mathrm{O}^{1} \mathrm{D}+\mathrm{H}_{2} \mathrm{O}$ and $43 \%$ from $\mathrm{O}_{3}+$ alkenes. Only $3 \%$ of initiation via $\mathrm{OH}$ occurred through HONO photolysis at this time. Production of $\mathrm{OH}$ from $\mathrm{HONO}$ photolysis during TORCH was greatest between 24 and 28 August. 
Table 1. Reaction rates for major processes in units of $10^{5}$ molecule $\mathrm{cm}^{-3} \mathrm{~s}^{-1}$ during daylight hours between 11:00 and 15:00. Also shown are average measured concentrations of selected input parameters, the $\mathrm{O}_{3}$ production rate and the chainlength (see text). 11 August is excluded due to power failure. Heatwave period is highlighted in red.

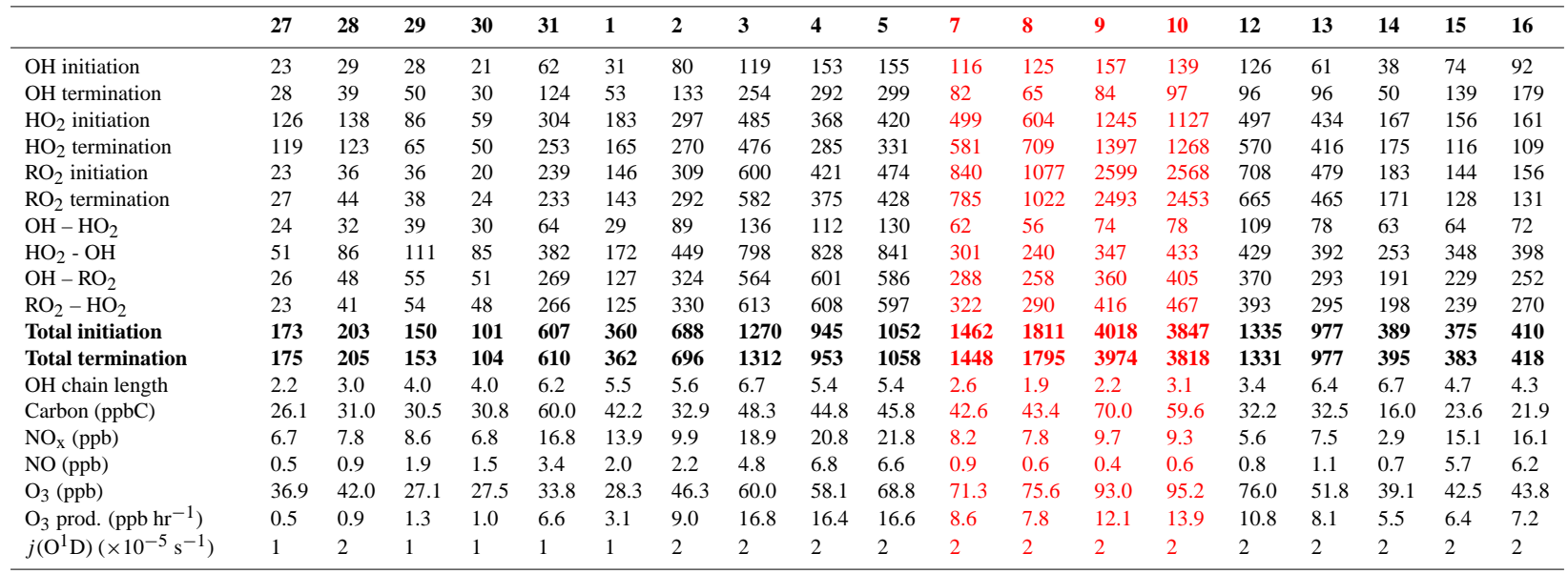

Table 1. Continued.

\begin{tabular}{|c|c|c|c|c|c|c|c|c|c|c|c|c|c|c|c|c|}
\hline & 17 & 18 & 19 & 20 & 21 & 22 & 23 & 24 & 25 & 26 & 27 & 28 & 29 & 30 & $\begin{array}{l}\text { Average } \\
\text { heatwave }\end{array}$ & $\begin{array}{l}\text { Campaign } \\
\text { Average }\end{array}$ \\
\hline $\mathrm{OH}$ initiation & 113 & 74 & 37 & 52 & 35 & 24 & 28 & 111 & 47 & 62 & 60 & 59 & 38 & 34 & 134 & 73 \\
\hline $\mathrm{OH}$ termination & 228 & 119 & 57 & 93 & 66 & 46 & 25 & 200 & 93 & 132 & 125 & 117 & 72 & 72 & 82 & 110 \\
\hline $\mathrm{HO}_{2}$ initiation & 275 & 542 & 222 & 290 & 234 & 135 & 178 & 161 & 127 & 131 & 164 & 77 & 177 & 143 & 869 & 310 \\
\hline $\mathrm{HO}_{2}$ termination & 195 & 508 & 206 & 257 & 204 & 119 & 177 & 104 & 101 & 96 & 129 & 50 & 160 & 115 & 989 & 300 \\
\hline $\mathrm{RO}_{2}$ initiation & 267 & 550 & 209 & 281 & 199 & 111 & 168 & 146 & 118 & 144 & 169 & 87 & 178 & 125 & 1771 & 466 \\
\hline $\mathrm{RO}_{2}$ termination & 244 & 542 & 212 & 278 & 202 & 109 & 178 & 124 & 112 & 117 & 148 & 63 & 174 & 124 & 1688 & 440 \\
\hline $\mathrm{HO}_{2}-\mathrm{OH}$ & 611 & 443 & 270 & 355 & 243 & 162 & 163 & 480 & 327 & 303 & 354 & 230 & 295 & 273 & 330 & 347 \\
\hline $\mathrm{OH}-\mathrm{RO}_{2}$ & 405 & 337 & 202 & 253 & 178 & 117 & 134 & 313 & 205 & 186 & 234 & 140 & 200 & 186 & 328 & 254 \\
\hline $\mathrm{RO}_{2}-\mathrm{HO}_{2}$ & 411 & 331 & 196 & 250 & 170 & 116 & 123 & 325 & 210 & 209 & 251 & 161 & 202 & 187 & 374 & 265 \\
\hline Total initiation & 656 & 1168 & 469 & 624 & 470 & 271 & 375 & 419 & 293 & 337 & 394 & 223 & 394 & 303 & 2785 & 805 \\
\hline Total termination & 667 & 1170 & 475 & 629 & 472 & 273 & 380 & 427 & 307 & 345 & 403 & 230 & 406 & 311 & 2759 & 808 \\
\hline $\mathrm{OH}$ chain length & 5.4 & 6.0 & 7.3 & 6.8 & 6.9 & 6.8 & 5.8 & 4.3 & 7.0 & 4.9 & 5.9 & 3.9 & 7.8 & 8.0 & 2.4 & 5.2 \\
\hline Carbon (ppbC) & 24.9 & 42.9 & 17.9 & 24.3 & 27.6 & 25.1 & 17.2 & 25.3 & 19.6 & 40.4 & 21.1 & 26.5 & 17.8 & 14.2 & 53.9 & 32.7 \\
\hline $\mathrm{NO}_{\mathrm{X}}(\mathrm{ppb})$ & 15.8 & 11.1 & 3.8 & 5.7 & 8.5 & 8.8 & 1.8 & 16.0 & 8.4 & 16.6 & 11.0 & 23.1 & 7.2 & 4.7 & 8.8 & 10.8 \\
\hline $\mathrm{O}_{3}(\mathrm{ppb})$ & 49.9 & 49.4 & 42.0 & 48.2 & 34.6 & 20.8 & 28.3 & 35.5 & 35.5 & 34.3 & 36.2 & 29.9 & 36.8 & 34.9 & 83.8 & 46.5 \\
\hline $\mathrm{O}_{3}$ prod. $(\mathrm{ppb} \mathrm{hr}-1)$ & 11.2 & 8.8 & 5.3 & 6.8 & 4.5 & 3.0 & 3.3 & 9.2 & 6.1 & 5.7 & 6.8 & 4.3 & 6.0 & 5.0 & 10.6 & 7.2 \\
\hline$j\left(\mathrm{O}^{1} \mathrm{D}\right)\left(\times 10^{-5} \mathrm{~s}^{-1}\right)$ & 2 & 1 & 2 & 2 & 1 & 1 & 1 & 1 & 1 & 1 & 1 & 1 & 1 & 1 & 2 & 1 \\
\hline
\end{tabular}

Table 1 shows that maximum initiation via $\mathrm{OH}$ took place on 9 August at a rate of $157 \times 10^{5}$ molecule $\mathrm{cm}^{-3} \mathrm{~s}^{-1} .9 \mathrm{Au}-$ gust was within the heatwave period, when the average concentration of measured VOCs was $70 \mathrm{ppbC}$, with corresponding $\mathrm{NO}_{\mathrm{x}}$ and $\mathrm{O}_{3}$ concentrations of 10 and $93 \mathrm{ppb}$, respectively (Table 1). Lowest initiation via $\mathrm{OH}$ took place during a north Atlantic/northern UK trajectory path on 30 July with a production rate of just $21 \times 10^{5}$ molecule $\mathrm{cm}^{-3} \mathrm{~s}^{-1}$. Measured VOC concentrations on this day were $31 \mathrm{ppbC}$, with $\mathrm{NOx}$ at $7 \mathrm{ppb}$ and an $\mathrm{O}_{3}$ concentration of $37 \mathrm{ppb}$.

Radical termination via $\mathrm{OH}$ during $\mathrm{TORCH}$ was due mainly to reaction with $\mathrm{NO}_{\mathrm{x}}$ species, $\mathrm{NO}_{2}(57 \%)$ and $\mathrm{NO}$ (16\%). Average concentrations of $\mathrm{NO}$ and $\mathrm{NO}_{2}$ over the
TORCH campaign were $3 \mathrm{ppb}$ and $8 \mathrm{ppb}$, respectively, giving an NO: $\mathrm{NO}_{2}$ ratio of 0.4 , similar to that found for the summer PUMA campaign (Emmerson et al., 2005a). Other important reactions were with various unsaturated species $(9 \%)$, PAN species $(8 \%)$ and organic nitrates $(6 \%)$. The dominance of the nitrated species is clear, and shows how termination of the $\mathrm{OH}$ radical is almost entirely $(88 \%)$ dependent on them. There are 216 different PAN species in the model, which are formed when acetyl peroxy radicals (of general formula $\mathrm{RCO}_{3}$ ) react with $\mathrm{NO}_{2}$. They each react with $\mathrm{OH}$ to form carbonyl species, $\mathrm{CO}$ and $\mathrm{NO}_{2}$, albeit slowly, and the cumulative effect of these reactions can impact the resulting $\mathrm{OH}$ concentration under the right conditions. 


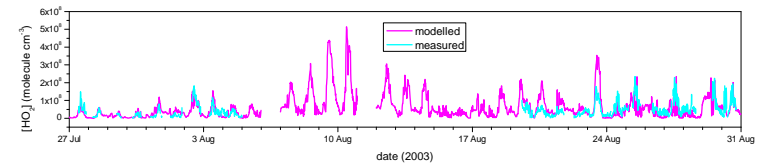

Fig. 3. Time series in modelled (magenta) and measured (cyan) $\mathrm{HO}_{2}$ concentrations during the TORCH 2003 campaign. Data are shown as 15-min averages for direct comparison. Data are shown as 15-min averages for direct comparison. Measured data during the heatwave period are missing owing to technical problems.

Reaction with $\mathrm{NO}_{2}$ is more important during the early part of the campaign causing termination of $71 \%$ of the $\mathrm{OH}$ radicals with a further $14 \%$ through reaction with NO. During the heatwave period, $56 \%$ of $\mathrm{OH}$ is lost through reaction with $\mathrm{NO}_{2}$ but only $4 \%$ lost due to reaction with NO. The air mass was stagnant under these conditions and therefore aged, containing mainly secondary oxidised species. Hence, PAN species account for $13 \%$ of $\mathrm{OH}$ termination, with unsaturated species $14 \%$ during the heatwave. Greatest $\mathrm{OH}$ termination takes place on 5 August with $299 \times 10^{5}$ molecule $\mathrm{cm}^{-3} \mathrm{~s}^{-1}$ and the lowest rate is $28 \times 10^{5}$ molecule $\mathrm{cm}^{-3} \mathrm{~s}^{-1}$ on 27 July (Table 1).

\subsection{The Hydroperoxy Radical, $\mathrm{HO}_{2}$}

Diurnal profiles in $\left[\mathrm{HO}_{2}\right]$ were much less pronounced than for $[\mathrm{OH}]$ and in several cases asymmetric about noon with secondary peaks in $\left[\mathrm{HO}_{2}\right]$ occurring in the late afternoon/early evening. Noon-time maxima varied between $0.16-3.3 \times 10^{8}$ molecule $\mathrm{cm}^{-3}(0.6-13.5 \mathrm{pptV})$. There were night-time $\mathrm{HO}_{2}$ radicals above the daily calculated nighttime detection limit on nine nights of the campaign (mean night-time detection limit $1.3 \times 10^{6}$ molecule $\mathrm{cm}^{-3}$, for a signal-to-noise ratio of 1 and an averaging period of $15 \mathrm{~min}$, with 5 min off-line to establish the background signal) with concentrations of between 0.02 and $1.00 \times 0^{8}$ molecule $\mathrm{cm}^{-3}$ $(0.1-4.1 \mathrm{pptV}$ ). A peak in $\mathrm{NO}$ at $\sim 06: 00 \mathrm{~h}$ (attributed to a combination of the collapse in the boundary layer and morning rush hour traffic) causes a concurrent suppression in $\mathrm{HO}_{2}$. Despite a rise in the rate of recycling of $\mathrm{HO}_{2}$ via reaction with $\mathrm{NO}$, there is no rise in $[\mathrm{OH}]$ as this increased $\mathrm{OH}$ production is balanced out by an increased destruction through reaction with $\mathrm{NO}_{2}$ and other $\mathrm{OH}$ sinks that are expelled with $\mathrm{NO}_{\mathrm{x}}$ (e.g. VOCs). The 24-hour mean $\left[\mathrm{HO}_{2}\right]$ for the entire campaign (derived from hourly averages) was found to be $6.2 \times 10^{7}$ molecule $\mathrm{cm}^{-3}(2.5 \mathrm{pptV})$.

The time series of modelled and measured $\mathrm{HO}_{2}$ concentrations is shown in Fig. 3. The model comparison with measurements is generally very good and particularly during the early part of the campaign between 28-30 July and also after 25 August. Peak concentrations are $6.1 \times 10^{7}$ molecule

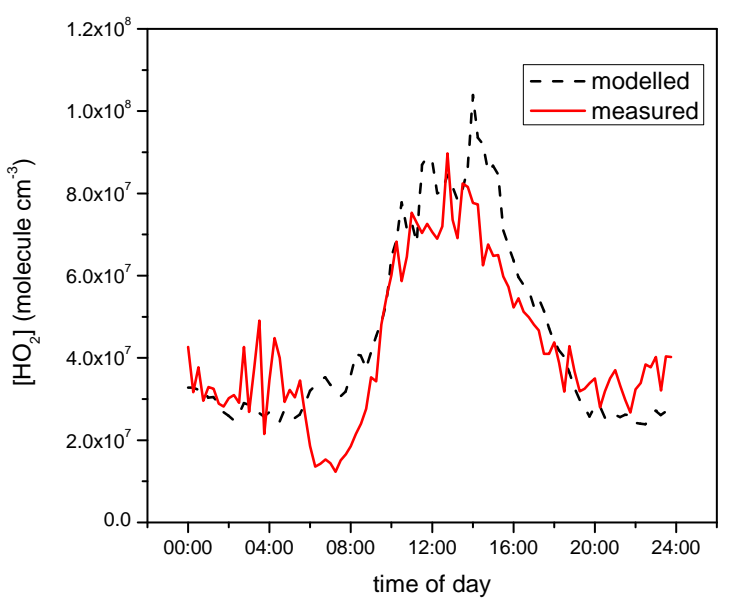

Fig. 4. 15-min average modelled and measured $\mathrm{HO}_{2}$ concentrations plotted as a diurnal time series. Modelled data are dashed black lines, measured data are red. (Number of data points contributing to the mean measured data varies between 23 and 96).

$\mathrm{cm}^{-3}$ for model and measured $\mathrm{HO}_{2}$ between 28-30 July and $2.1 \times 10^{8}$ and $2.4 \times 10^{8}$ molecule $\mathrm{cm}^{-3}$ for model and measurements respectively, after 25 August. The model tends to over-predict during the westerly air parcels between 19 and 24 August with the majority of the over-prediction occurring after noon. Modelled $\mathrm{HO}_{2}$ on 23 August is a factor of 2 higher between 11:00-15:00 h than the measurements and is the most significant departure in agreement for the whole campaign. Generally there is a slight model under-prediction of the measurements during the latter period of the campaign.

The agreement between model and measurements is very good. In previous campaigns employing measurementconstrained models, $\mathrm{HO}_{2}$ measurements have generally been significantly over-predicted by the model (Carslaw et al., 2001, 2002; Sommariva et al., 2004) or under-predicted (Martinez et al., 2003; Emmerson et al., 2005a; Ren et al., 2006). An important difference in the current work is a better representation of the heterogeneous loss of $\mathrm{HO}_{2}$ to aerosol surface reactions, which was found previously to make a large difference in the marine boundary layer (Haggerstone et al., 2005). In addition, many more species are constrained than in most previous campaigns including more oxygenated species, some of which play a key role in radical initiation via $\mathrm{HO}_{2}$ as shown subsequently.

Figure 4 shows the modelled and measured $\mathrm{HO}_{2}$ data as two diurnal plots. Each 15 min period of the day has been averaged for all the days where there are model and measurement data available. The greatest deviation between model and measurements occurs between 06:00-08:30 but agreement is excellent before and after this period. $\mathrm{HO}_{2}$ initiation at this time is dominated by the photolysis of carbonyl 


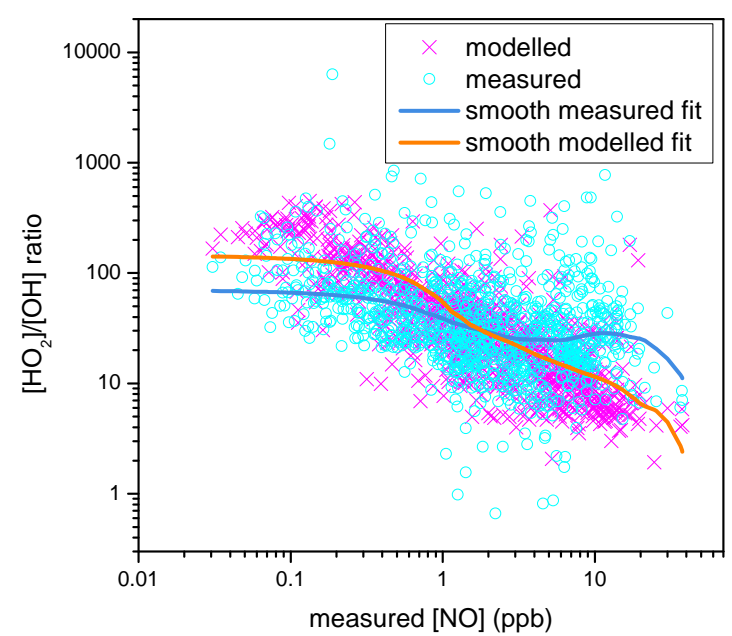

Fig. 5. Modelled (magenta) and measured (cyan) $\mathrm{HO}_{2}: \mathrm{OH}$ ratios plotted against measured NO concentrations. Data are shown as 15-min averages for direct comparison. Also shown are smoothed fits through each data-set (see text).

species, so the model may be overestimating their impact early in the morning.

The reaction rates for initiation and termination via $\mathrm{HO}_{2}$ radicals are shown in Table 1. During the first four days of the campaign, photolysis of $\mathrm{HCHO}$ produces $62 \%$ of new $\mathrm{HO}_{2}$ radicals, but becomes less important for the rest of the campaign (24\%) as photolysis of the groups of dicarbonyl and aldehyde species contributes $44 \%$ and $29 \%$ on average, respectively. The rate of initiation via $\mathrm{HO}_{2}$ varies between $59 \times 10^{5}$ molecule $\mathrm{cm}^{-3} \mathrm{~s}^{-1}$ on 30 July, to $1245 \times$ $10^{5}$ molecule $\mathrm{cm}^{-3} \mathrm{~s}^{-1}$ on 9 August.

With the addition of the new heterogeneous loss mechanism via aerosols for $\mathrm{HO}_{2}$ in TORCH, aerosol surface was responsible for $83 \%$ of $\mathrm{HO}_{2}$ termination reactions. Maximum termination of $\mathrm{HO}_{2}$ radicals took place on 9 August $\left(1397 \times 10^{5}\right.$ molecule $\left.\mathrm{cm}^{-3} \mathrm{~s}^{-1}\right)$. The aerosol termination route is greatest during the early part of the campaign, when aerosol surface to volume ratios were largest (maximum value of the rate coefficient, $\mathrm{k}_{t}$ was 0.8 molecule $\mathrm{cm}^{-3}$ ). This result demonstrates the need for an accurate determination of the accommodation coefficient for $\mathrm{HO}_{2}$ under typical urban and suburban conditions. The calculation of the termination rate owing to this reaction depends critically on the accommodation coefficient used, the value of which is subject to significant uncertainty as discussed earlier. The chemistry during the campaign differs in terms of the dominant $\mathrm{HO}_{2}$ initiation and termination reactions. As a campaign average, initiation via $\mathrm{HO}_{2}$ occurs mainly through dicarbonyl photolysis (44\%), aldehyde photolysis (29\%) and HCHO photolysis $(24 \%)$. During the heatwave period, there was a similar

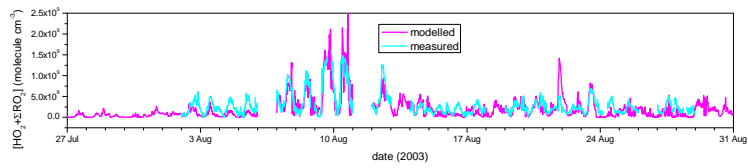

Fig. 6. Time series in modelled (magenta) and measured (cyan) $\left[\mathrm{HO}_{2}+\Sigma \mathrm{RO}_{2}\right]$ concentrations during the TORCH 2003 campaign at Writtle. Data are shown as 15-min averages for direct comparison.

contribution from dicarbonyl species (42\%), with less from the photolysis of formaldehyde (15\%) and more from other aldehyde species $(35 \%)$. Termination of $\mathrm{HO}_{2}$ was always dominated by loss to aerosol particles in all regimes, $(83 \%$ on average and $87 \%$ for the heatwave period). These results confirm the suggestion of Saylor (1997), that under polluted conditions, the magnitude of heterogeneous $\mathrm{HO}_{2}$ loss may be a significant fraction of the gas-phase chemical loss.

\section{3 $\mathrm{HO}_{2}$ : OH Ratios}

15 min modelled and measured $\mathrm{HO}_{2}: \mathrm{OH}$ ratios are plotted against measured $\mathrm{NO}$ concentrations in Fig. 5. $\mathrm{HO}_{2}$ reacts with $\mathrm{NO}$ to regenerate $\mathrm{OH}$; therefore the $\mathrm{HO}_{2}: \mathrm{OH}$ ratio will decrease at higher concentrations of NO (Stevens et al., 1997; Ren et al., 2003). On average NO concentrations were $2.8 \mathrm{ppb}$ during the campaign, with a peak of $\sim 45 \mathrm{ppb}$ on 28 July. Figure 5 shows much more scatter in the measured data with NO compared with the modelled as would be expected.

To highlight the relationships in Fig. 5, locally weighted regression smoothing (LOESS) lines have been fitted (Cleveland, 1979). These show that both the measured and modelled ratios decrease with increasing NO as expected. However, the measured ratio shows a much shallower slope than the model. Modelled $\mathrm{HO}_{2}: \mathrm{OH}$ ratios also showed a stronger relationship with NO than measured, in the PUMA summer campaign of 1999 (Emmerson et al., 2005a), at PMTACs (Ren et al., 2003), and during BERLIOZ (Konrad et al., 2003). The TORCH results are also similar to those found during a rural study in central Pennsylvania (Ren et al., 2005), except that the point where the measured and modelled slopes crossed was at $\sim 0.2 \mathrm{ppb} \mathrm{NO}$ ca. $2 \mathrm{ppb}$ for TORCH. Ren et al. (2005) concluded that the $\mathrm{HO}_{2} / \mathrm{OH}$ ratio variation as a function of NO was not well captured by their model and the same conclusion can be applied to the TORCH campaign and the other studies quoted. The reason for this discrepancy is not readily apparent, but clearly warrants further investigation. 


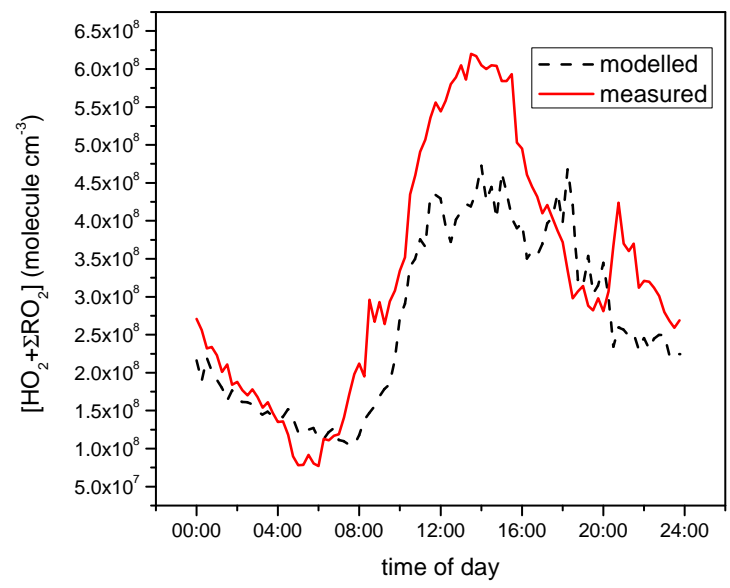

Fig. 7. 15-min average modelled and measured $\left[\mathrm{HO}_{2}+\Sigma \mathrm{RO}_{2}\right]$ concentrations plotted as a diurnal time series. Modelled data are black dashed lines, measured data are red. (Number of data points contributing to the mean measured data varies between 22 and 96).

\subsection{Hydroperoxy and the Sum of Organic Peroxy Radicals,} $\left[\mathrm{HO}_{2}+\Sigma \mathrm{RO}_{2}\right]$

The time series of modelled to measured $\left[\mathrm{HO}_{2}+\Sigma \mathrm{RO}_{2}\right]$ is shown in Fig. 6. The campaign average diurnal cycle of measured $\left[\mathrm{HO}_{2}+\Sigma \mathrm{RO}_{2}\right]$ is similar in shape and magnitude to that from the BERLIOZ campaign (Volz-Thomas et al., 2003). In both cases concentrations have a broad midday to mid-afternoon peak before falling off to a minimum at around 18:00 to 19:00 h. A smaller maximum occurs at 20:00 to 21:00 h followed by a gradual drop in concentrations to a minimum at 05:00 to 06:00 h. The daytime maximum mixing ratio is somewhat higher for TORCH than for BERLIOZ although the agreement is much better if the values from the heatwave period are not included in the average.

There is an under-prediction in the modelled $\left[\mathrm{HO}_{2}+\right.$ $\Sigma \mathrm{RO}_{2}$ ] when compared to the measurements, in contrast to the good agreement when $\mathrm{HO}_{2}$ radicals are considered alone. The $15 \mathrm{~min}$ average diurnal sequence for the whole campaign is shown in Fig. 7. Excellent agreement is observed over night between 00:00 and 03:45 h, with a departure following sunrise for the duration of the daylight period of the day. The measured $\mathrm{RO}_{2}: \mathrm{HO}_{2}$ ratio (calculated by subtracting measured $\mathrm{HO}_{2}$ by FAGE from the $\left(\mathrm{HO}_{2}+\Sigma \mathrm{RO}_{2}\right)$ concentrations measured by PERCA) is 6.8 as a campaign average over the 11:00-15:00 $\mathrm{h}$ period compared to 3.9 for the equivalent model value. Both of these values are high compared to the BERLIOZ campaign, where the equivalent ratio was 1.0 (Holland et al., 2003).

The majority of radical initiation via $\mathrm{RO}_{2}$ between 11:00 and 15:00 $\mathrm{h}$ averaged over the campaign, occurs through the photolysis of dicarbonyl species $(40 \%), \mathrm{O}_{3}+$ alkenes $(22 \%)$ and the photolysis of aldehydes (17\%). During the heatwave period this does not alter significantly with $30 \%$ and $17 \%$ for the photolysis of dicarbonyl species and aldehydes respectively, and $29 \%$ from $\mathrm{O}_{3}$ +alkenes. $\mathrm{RO}_{2}$ termination mechanisms include PAN production from $\mathrm{RCO}_{3}(72 \%)$, with $20 \%$ occurring on reaction with $\mathrm{NO}$ for the whole campaign, but the PAN route represents $63 \%$ and NO route represents $12 \%$ of the heatwave $\mathrm{RO}_{2}$ sink, due to the stagnation of the air mass and therefore higher $\mathrm{NO}_{2}$ concentrations. A further $17 \%$ of termination via $\mathrm{RO}_{2}$ is through $\mathrm{RO}_{2}+\mathrm{HO}_{2}$ reactions in the heatwave period, which corresponds to $5 \%$ over the whole campaign. On balance, the PAN species act as a net termination route for $\mathrm{RCO}_{3}$ radicals under the TORCH conditions. Note that the point at which PAN species switch from being net radical sinks to sources is a complex function of $\mathrm{NO}_{\mathrm{x}}, \mathrm{O}_{3}$ and VOC concentrations as well as temperature.

One striking feature of the datasets is that the modelled $\mathrm{HO}_{2}$ and $\mathrm{RO}_{2}$ levels, and the measured $\mathrm{RO}_{2}$, are significantly higher during the heatwave period than for the rest of the campaign. Interestingly, the modelled $\mathrm{OH}$ does not appear to be elevated, suggesting that in the heatwave period, there were more sources and sinks of $\mathrm{OH}$ and so there was a degree of buffering of the resulting $\mathrm{OH}$ concentration. In fact, Table 1 shows that although $\mathrm{OH}$ initiation increased in importance under heatwave conditions, the total flux of $\mathrm{OH}$ to $\mathrm{RO}_{2}$ also increased acting as a counter-balance.

\subsection{Radical Propagation}

The total average transfer of $\mathrm{OH} \rightarrow \mathrm{HO}_{2}$ radicals during the TORCH campaign is $66 \times 10^{5}$ molecule $\mathrm{cm}^{-3} \mathrm{~s}^{-1}$ and occurs mainly through reaction with $\mathrm{CO}(38 \%)$, with contributions from HCHO (16\%), alcohols (15\%), methane (13\%), and aromatics $(8 \%)$. Table 1 shows the absolute reaction rates of transfer for daylight hours, and that the reverse route of $\mathrm{HO}_{2} \rightarrow \mathrm{OH}\left(347 \times 10^{5}\right.$ molecule $\mathrm{cm}^{-3} \mathrm{~s}^{-1}$ on average) is approximately 5 times greater than the flux in the $\mathrm{OH} \rightarrow \mathrm{HO}_{2}$ direction. This reverse flux is dominated by reaction of $\mathrm{HO}_{2}$ with $\mathrm{NO}(\sim 99 \%)$, which produces around $80 \%$ of the $\mathrm{OH}$ radicals, slightly more than the $70 \%$ observed during BERLIOZ (Mihelcic et al., 2003).

On average across the whole campaign, the $\mathrm{OH} \rightarrow \mathrm{RO}_{2}$ flux $\left(254 \times 10^{5}\right.$ molecule $\left.\mathrm{cm}^{-3} \mathrm{~s}^{-1}\right)$ is balanced by the $\mathrm{RO}_{2} \rightarrow \mathrm{HO}_{2}$ flux $\left(265 \times 10^{5}\right.$ molecule $\left.\mathrm{cm}^{-3} \mathrm{~s}^{-1}\right)$. Isoprene, the main biogenic constituent measured during TORCH had an average concentration of $0.1 \mathrm{ppb}$ (with a maximum of 1.3 $\mathrm{ppb}$ on 10 August and was responsible for $6 \%$ of $\mathrm{OH} \rightarrow \mathrm{RO}_{2}$, with additional contributions from aldehydes $(40 \%)$, alkenes $(15 \%)$, ketones $(10 \%)$, alkanes $(9 \%)$ and aromatic species $(8 \%)$.

As the closest example for comparison, the Pollution of the Urban Midlands Atmosphere (PUMA) summer campaign (Emmerson et al., 2005a,b; Harrison et al., 2006; Heard et al., 2004) took place in Birmingham city centre during 1999. The percentage contributions to initiation 


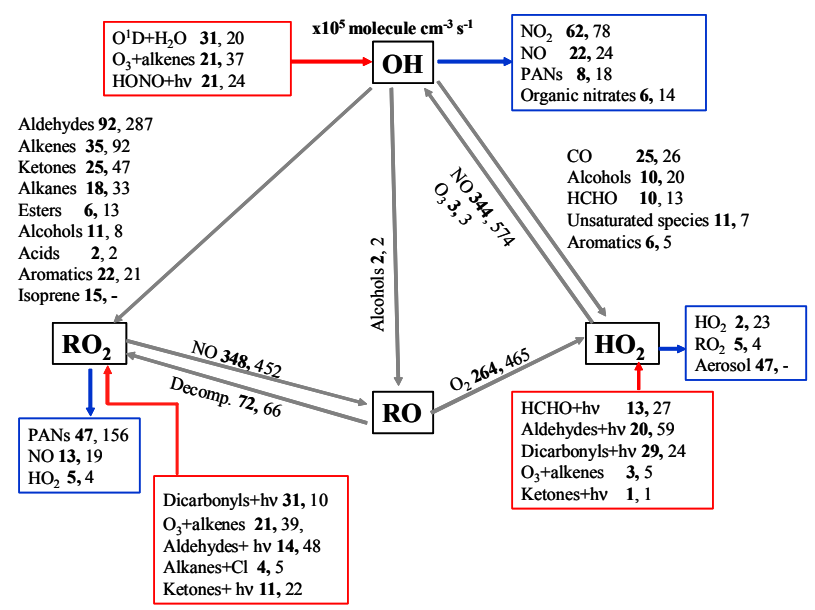

Fig. 8. Fluxes of species contributing to initiation, termination and propagation via $\mathrm{OH}, \mathrm{HO}_{2}, \mathrm{RO}_{2}$, and $\mathrm{RO}$ radicals for the TORCH (heavy type) and PUMA summer campaigns (light type) between 11:00-15:00 h. Units in $10^{5}$ molecule $\mathrm{cm}^{-3} \mathrm{~s}^{-1}$.

via $\mathrm{OH}$ during the PUMA campaign were similar to the findings for TORCH in the current work. For example in the summer PUMA campaign, $46 \%$ of initiation via $\mathrm{OH}$ came from $\mathrm{O}_{3}+$ alkenes reactions, $29 \%$ from HONO photolysis and $24 \%$ from $\mathrm{O}\left({ }^{1} \mathrm{D}\right)+\mathrm{H}_{2} \mathrm{O}$. Photolysis of ozone was not the dominant initiation reaction as for TORCH. Average concentrations of $\mathrm{O}_{3}$ were $26 \mathrm{ppb}$ for PUMA and $47 \mathrm{ppb}$ for TORCH; average $\mathrm{j}\left(\mathrm{O}\left({ }^{1} \mathrm{D}\right)\right)$ was $3.6 \times 10^{-6} \mathrm{~s}^{-1}$ for PUMA and $4.7 \times 10^{-6} \mathrm{~s}^{-1}$ for TORCH; and average $\mathrm{H}_{2} \mathrm{O}$ concentrations were $3.6 \times 10^{17}$ molecule $\mathrm{cm}^{-3}$ for PUMA and $3.7 \times 10^{17}$ molecule $\mathrm{cm}^{-3}$ for TORCH. In other campaigns, the reaction of $\mathrm{O}^{1} \mathrm{D}+\mathrm{H}_{2} \mathrm{O}$ was a major source of $\mathrm{OH}$ during the Nashville Southern Oxidants Study (SOS) in the USA (Martinez et al., 2003), with photolysis of HONO and formaldehyde becoming more important as the UV light diminished at the ends of the day. By contrast, photolysis of HONO dominated $\mathrm{OH}$ production in New York during the $\mathrm{PM}_{2.5}$ Technology Assessment and Characterisation study (PMTACs; Ren et al., 2003).

The reaction rate analyses are summarised in Fig. 8, which shows radical cycling between $\mathrm{OH}, \mathrm{HO}_{2}, \mathrm{RO}_{2}$ and $\mathrm{RO}$ radicals. The values shown are average reaction rates over the whole campaign between 11:00 and 15:00 h. The corresponding PUMA summer campaign reaction rates are shown for comparison. The first thing to note is that the magnitude of the reaction rates in the two campaigns is very similar. TORCH is a sub-urban site 25 miles from London, and has cleaner air, unless air parcels travel directly from the London direction. By contrast, PUMA was designed to measure the polluted urban atmosphere by nature of the site position near Birmingham city centre (Harrison et al., 2006). Average modelled concentrations of $\mathrm{OH}, \mathrm{HO}_{2}$ and $\left(\mathrm{HO}_{2}+\Sigma \mathrm{RO}_{2}\right)$

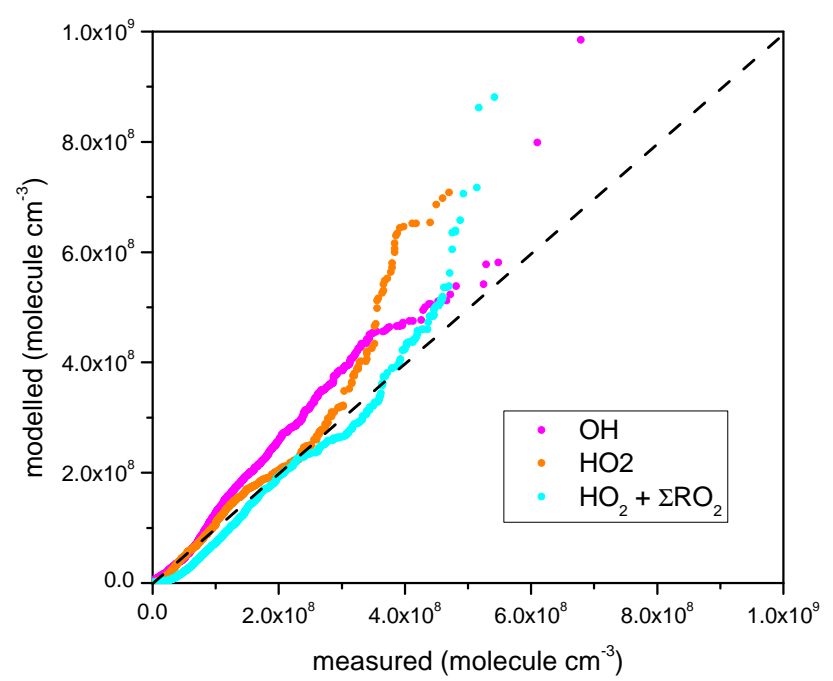

Fig. 9. QQ plot showing simultaneous modelled and measured $\mathrm{OH}$ (magenta), $\mathrm{HO}_{2}$ (orange) and $\left(\mathrm{HO}_{2}+\Sigma \mathrm{RO}_{2}\right)$ (cyan) concentrations. $\mathrm{OH}$ data are multiplied by $100, \mathrm{HO}_{2}$ by two and $\left(\mathrm{HO}_{2}+\Sigma \mathrm{RO}_{2}\right)$ is divided by 3. A 1-1 line is shown for comparison.

over the same time period for the TORCH (t) and PUMA (p) campaigns were as follows: $\mathrm{OH}_{t}=2.8 \times 10^{6}, \mathrm{OH}_{p}=2.7 \times$ $10^{6}, \mathrm{HO}_{2 t}=1.2 \times 10^{8}, \mathrm{HO}_{2 p}=1.4 \times 10^{8}, \mathrm{RO}_{2 t}=1.9 \times 10^{8}$, $\mathrm{RO}_{2 p}=1.5 \times 10^{8}$ molecule $\mathrm{cm}^{-3}$.

Figure 8 demonstrates that there were greater concentrations of hydrocarbons in the atmosphere during PUMA, shown by the larger reaction rates of $\mathrm{OH} \rightarrow \mathrm{RO}_{2}$ via aldehyde species and through $\mathrm{OH}$ reactions with alkenes and ketones, for example.

\subsection{Quantile-Quantile plots}

A quantile-quantile (QQ) plot for modelled and measured radical concentrations is shown in Fig. 9. For ease of comparison $\mathrm{OH}, \mathrm{HO}_{2}$ and $\left[\mathrm{HO}_{2}+\Sigma \mathrm{RO}_{2}\right]$ modelled and measured data have been shown on the same plot, with $\mathrm{OH}$ data multiplied by 100 and $\left[\mathrm{HO}_{2}+\Sigma \mathrm{RO}_{2}\right]$ divided by 3 . Data have been averaged to $15 \mathrm{~min}$, and then ranked in ascending order. This process identifies potential systematic biases in the model or the measurements. If the model and measurements were exactly alike they would fall on the 1:1 line. At low concentrations of $\mathrm{OH}$ the model and measurements are similar, but the modelled data become greater than the measurements once concentrations exceed $6.3 \times 10^{5}$ molecule $\mathrm{cm}^{-3}$. On average, the model over-predicts the $\mathrm{OH}$ measurements by $24 \%$. The plot moves closer to the 1:1 line again for concentrations greater than about $4 \times 10^{6}$ molecule $\mathrm{cm}^{-3}$. This observation ties in with the diurnal plot (Fig. 2) which showed that the best model agreement occurred at the ends of the day.

The excellent model to measured $\mathrm{HO}_{2}$ agreement is evident in Fig. 9, where ranked 15-min average concentrations 


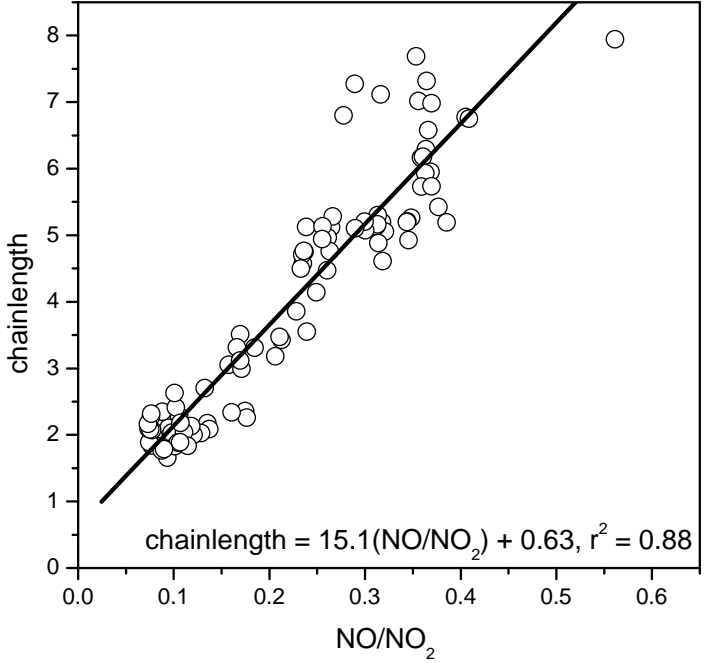

Fig. 10. Correlation plot of the $\mathrm{NO}: \mathrm{NO}_{2}$ ratio against the chainlength for the TORCH 2003 campaign.

of modelled and measured $\mathrm{HO}_{2}$ are very well matched. Modelled $\mathrm{HO}_{2}$ concentrations are greater than measured at around $1.7 \times 10^{8}$ molecule $\mathrm{cm}^{-3}$. On average the model over-predicts the measurements by just $7 \%$. By contrast, $\left[\mathrm{HO}_{2}+\Sigma \mathrm{RO}_{2}\right]$ modelled data under-predicts - the measurements from PERCA on average by $22 \%$.

\subsection{OH Radical Chain Lengths and Local Ozone Produc- tion}

The radical chain length can be defined as the ratio of the number of radicals propagated to the number of radicals formed through initiation. The chain length for $\mathrm{OH}$ is shown at the bottom of Table 1 between 11:00 and 15:00 h, and corresponds to the $\mathrm{HO}_{2} \rightarrow \mathrm{OH}$ route divided by $\mathrm{OH}$ initiation. The chain length is therefore a measure of the efficiency of the recycling of the $\mathrm{OH}$ radical once formed. For TORCH, the modelled $\mathrm{OH}$ chain length varied between 2 (on July 27, 8 and 9 August) and 8 (on 29 and 30 August). This is similar to chain lengths between 3 and 8 calculated during the SOS campaign downwind of Nashville in the USA (Martinez et al., 2003). On a diurnal timescale, the maximum chainlength coincided with the maximum $\mathrm{NO}_{\mathrm{x}}$ concentration as noted by Martinez et al. (2003), although in the case of TORCH, the maximum occurred during morning rush hour rather than around midday as observed in Nashville.

8 and 9 August fall in the polluted period of the TORCH campaign, yet have very low radical chain lengths. This observation can be explained by investigating the effect of the $\mathrm{NO}: \mathrm{NO}_{2}$ ratio on chainlength, as shown in Fig. 10. The lowest values of the chainlength coincide with lower $\mathrm{NO}: \mathrm{NO}_{2}$ ratios, air masses which can be thought of as aged. The higher NO: $\mathrm{NO}_{2}$ ratios, or air masses which have been subject to recent emissions, have much higher chainlengths. During the heatwave, air was circulating round in stagnant conditions and it is likely that $\mathrm{NO}$ would have been converted to $\mathrm{NO}_{2}$ through reaction with $\mathrm{O}_{3}$. This observation agrees with the conclusions of Lee et al. (2006), who used hydrocarbon ratios to show that air reaching the site during the heat wave was highly processed and contained relatively high concentrations of secondary products such as ozone rather than primary emissions.

It is also interesting to calculate the local ozone production rate using the model. A zero-dimensional box model is employed in this work, which uses ozone as a model constraint. By summing all of the reaction rates for $\mathrm{NO}$ to $\mathrm{NO}_{2}$ conversions in the model, the $\mathrm{O}_{3}$ production rate from local chemistry can be calculated. The local $\mathrm{O}_{3}$ production rate is shown in Table 1 , and varies between $0.5 \mathrm{ppb} \mathrm{hr}^{-1}$ on 27 July to $17 \mathrm{ppb} \mathrm{hr}^{-1}$ on 3 and 5 August. Dates on which the local $\mathrm{O}_{3}$ production rate is higher than the campaign average (7.2 $\mathrm{ppb} \mathrm{hr}^{-1}$ ) are 2-13 August, 17-18 and 24. The ozone concentration is generally higher on these days ( $>45 \mathrm{ppb})$ than on the other days of the campaign, suggesting that local production plays an important role on these days. However, meteorological conditions also have a large impact on ozone concentrations. The $\mathrm{O}_{3}$ production rate on the 9-10 August is lower than the 3-5 August, but the ambient ozone concentration is higher. These issues will be investigated further in future publications.

\section{Conclusions}

The TORCH experiment was one of the most highly instrumented field campaigns to date and has resulted in the construction of a highly constrained photochemical box model to predict concentrations of radicals measured during the experiment. In general the model predicted the concentrations of all radicals well, over-predicting $\mathrm{OH}$ and $\mathrm{HO}_{2}$ concentrations by $24 \%$ and $7 \%$ respectively, and under-predicting measured $\left[\mathrm{HO}_{2}+\Sigma \mathrm{RO}_{2}\right]$ by $22 \%$. Indeed, the degree of model agreement with measured $\mathrm{HO}_{2}$ concentrations is the best reported under such conditions.

Initiation via $\mathrm{OH}$ was dominated by the reaction of $\mathrm{O}^{1} \mathrm{D}$ with water, except during a short period where photolysis of HONO became the major initiation route. The $\mathrm{OH}$ chain length varied between 2 and 8 , with the smaller chain lengths corresponding to more aged air masses. The largest modelled $\mathrm{O}_{3}$ production rate was $17 \mathrm{ppb} \mathrm{hr}^{-1}$ on 3 and 5 August. The absence of HONO measurements during the TORCH campaign was regrettable and leads to a model uncertainty. However, the same technique was used to estimate concentrations during the PUMA campaign, when estimated concentrations were in reasonable agreement with the few measured concentrations available (Emmerson et al., 2005a). In addition, 
the impact of HONO is likely to be greatest at dawn as shown through previous studies (Alicke et al., 2003) and the focus of the study here is on the hours around midday. Finally, the model tends to over-predict $\mathrm{OH}$, the opposite to that expected if a significant amount of $\mathrm{HONO}$ were absent. In conclusion, the omission of HONO is unlikely to be causing the over estimation of $\mathrm{OH}$ by the model.

Initiation via $\mathrm{HO}_{2}$ was dominated by aldehyde species, in particular HCHO between 11:00 and 15:00 h. However, during the heatwave period, the reaction of dicarbonyl species contributed more than the aldehydes. These results demonstrate the importance of measuring oxygenated species during field campaigns and highlight the need to speciate further species in future campaigns. Termination of $\mathrm{HO}_{2}$ was governed by heterogeneous chemistry on the surface of aerosols, and depended on their number concentrations. A major difference between this work and other campaigns such as PUMA is that termination of $\mathrm{HO}_{2}$ onto aerosol particles is a major pathway not previously considered in any detail, and could be important for all field campaigns with large sources and/or production rates of aerosol. Indeed, this termination rate may have been underestimated during the PUMA campaign owing to a lack of relevant data, although the higher $\mathrm{NO}_{\mathrm{x}}$ concentrations experienced during the PUMA campaign mean that this loss route would likely be less important than for TORCH. In addition, there is a need for relevant measurements of the $\mathrm{HO}_{2}$ accommodation coefficient to confirm aerosol loss of $\mathrm{HO}_{2}$ as a major termination route in more polluted areas.

Initiation via $\mathrm{RO}_{2}$ radicals occurs mainly through the photolysis of dicarbonyls and the reaction of $\mathrm{O}_{3}$ and alkenes. Termination is controlled though PAN formation and peroxyperoxy reactions. Although both the $\mathrm{HO}_{2}$ and $\mathrm{RO}_{2}$ concentrations are reproduced reasonably well by the model (the model in general overpredicts $\mathrm{HO}_{2}$ and underpredicts $\mathrm{RO}_{2}$ ), the high $\mathrm{RO}_{2}: \mathrm{HO}_{2}$ ratio of 6.8 is much higher than that predicted by the model (3.9). The reason for these high values compared with past campaigns (e.g. $\sim 1$ for BERLIOZ) and the difference between the modelled and measured ratios is currently unclear. It should be noted, however, that despite a significant difference between the modelled and measured ratio, both ratios during TORCH are considerably higher (e.g. factor of 4 for the model) than the ratios found during BERLIOZ.

The modelled radical initiation and termination budgets balanced very well. The propagation routes between $\mathrm{OH} \rightarrow \mathrm{HO}_{2}$ were governed by $\mathrm{CO}, \mathrm{HCHO}$ and alcohol species. The reverse flux $\left(\mathrm{HO}_{2} \rightarrow \mathrm{OH}\right)$ was 5 times greater than $\mathrm{OH} \rightarrow \mathrm{HO}_{2}$, and dominated by the reaction of $\mathrm{HO}_{2}$ with NO. The $\mathrm{OH} \rightarrow \mathrm{RO}_{2}$ route was dominated by aldehyde and alkene species.

The level of agreement between measured and modelled radical concentrations, even at a quite complex site, has given confidence that the model employed in this work has a reasonable representation of the chemistry of the atmosphere.
Having confidence in the model enables further elucidation of atmospheric processing through the rate of production analyses employed. Further analysis of the heatwave period of this campaign will be discussed in subsequent publications.

Acknowledgements. KME and NC would like to thank all of the scientists involved with the TORCH campaign, especially the groups of Hugh Coe (University of Manchester), Alastair Lewis (University of York), and Stuart Penkett (University of East Anglia), who made some of the measurements used to constrain or compare with the model. Some of the scientists involved in this project would also like to acknowledge the NERC Centre for Atmospheric Science for underpinning support. The Leeds group would like to acknowledge the technical assistance of G. P. Johnson. The TORCH project was funded via NERC grant number NER/T/S/2002/00498.

Edited by: W. T. Sturges

\section{References}

Alicke, B., Geyer, A., Hofzumahaus, A., Holland, F., Konrad, S., Pätz, H. W., Schäfer, J., Stutz, J., Volz-Thomas, A., and Platt, U.: $\mathrm{OH}$ formation by HONO photolysis during the BERLIOZ experiment, J. Geophys. Res., 108, doi:10.1029/2001JD000579, 2003.

Atkinson, R.: Atmospheric chemistry of VOCs and $\mathrm{NO}_{x}$, Atmos. Env., 34, 2063-2101, 2000.

Bloss, W. J., Gravestock, T. J., Heard, D. E., Ingham, T., Johnson, G. P., and Lee, J. D.: Application of a compact all solid-state laser system to the in situ detection of atmospheric $\mathrm{OH}, \mathrm{HO}_{2}$, $\mathrm{NO}$ and IO by laser-induced fluorescence, J. Env. Monitoring, 5, 21-28, 2003.

Brasseur, G. P., Hauglustaine, D. A., Walters, S., Rasch, P. J., Muller, J.-F., Granier, C., and Tie, X. X:. MOZART, a global chemical transport model for ozone and related chemical tracers. 1. Model description, J. Geophys. Res., 103, 28 265-28 289. 1998.

Carslaw, N., Creasey, D. J., Heard, D. E., Lewis, A. C., McQuaid, J. B., Pilling, M. J., Monks, P.S., Bandy, B. J., and Penkett, S. A.: Modelling $\mathrm{OH}, \mathrm{HO}_{2}$ and $\mathrm{RO}_{2}$ radicals in the marine boundary layer. 1. Model construction and comparison with field measurements, J. Geophys. Res., 104, 30 241-30 255, 1999.

Carslaw, N., Creasey, D. J., Harrison, D., Heard, D. E., Hunter, M. C., Jacobs, P. J., Jenkin, M. E., Lee, J. D., Lewis, A. C., Pilling, M. J., Saunders, S. M., and Seakins, P. W.: Modelling $\mathrm{OH}$ and $\mathrm{HO}_{2}$ radicals in a forested region of north-western Greece, Atmos. Env., 35, 4725-4737, 2001.

Clemitshaw, K. C., Carpenter, L. J., Penkett, S. A., and Jenkin, M. E.: A calibrated peroxy radical chemical amplifier for ground-based tropospheric measurements, J. Geophys. Res., 102, 25 405-25 416, 1997.

Cleveland, W. S.: Robust Locally Weighted Regression And Smoothing Scatterplots, J. Am. Stat. Assoc., 74(368), 829-836, 1979.

Derwent, R. G.: The influence of human activities on the distribution of hydroxyl radicals in the troposphere, Phil. Trans. R. Soc. London, Series A, 354, 501-531, 1996. 
Edwards, G. D. and Monks, P. S.: Performance of a single monochromator didoe array spectroradiometer for the determination of actinic flux and atmospheric photolysis frequencies, J. Geophys. Res., 108, 8546, doi:10.1029/2002JD002844.

Emmerson, K. M., Carslaw, N., Carpenter, L. J., Heard, D. E., Lee, J. D., and Pilling, M. J.: Urban Atmospheric Chemistry during the PUMA Campaign, 1: Comparison of Modelled $\mathrm{OH}$ and $\mathrm{HO}_{2}$ Concentrations with Measurements. J. Atmos. Chem., 52, no 2, 143-164, 2005a.

Emmerson, K. M., Carslaw, N., and Pilling, M. J.: Urban Atmospheric Chemistry during the PUMA Campaign. 2: Radical budgets for $\mathrm{OH}, \mathrm{HO}_{2}$ and $\mathrm{RO}_{2}$, J. Atmos. Chem., 52, no 2, 165-183, 2005b.

Fleming, Z. L., Monks, P. S., Rickard, A. R., Bandy, B. J., Brough, N., Green, T. J., Reeves, C. E., and Penkett, S. A.: Seasonal dependence of peroxy radical concentrations at a Northern hemisphere marine boundary layer site during summer and winter: Evidence for photochemical activity in winter, Atmos. Chem. Phys., 6, 5415-5433, 2006, http://www.atmos-chem-phys.net/6/5415/2006/.

Fleming, Z., Monks, P. S., Rickard, A. R., Heard, D. E., Bloss, W. J., Seakins, P. W., Still, T. J., Sommariva, R., Pilling, M. J., Morgan, R. B., Green, T. J., Brough, N., Mills, G. P., Penkett, S. A., Lewis, A. C., Lee, J. D., Saiz-Lopez, A., and Plane, J. M. C.: Peroxy radical chemistry and the control of ozone photochemistry at Mace Head, Ireland during the summer of 2002, Atmos. Chem. Phys., 6, 2193-2214, 2006, http://www.atmos-chem-phys.net/6/2193/2006/.

Frost, G. J., Trainer, M., Allwine, G., Buhr, M. P., Calvert, J. G., Cantrell, C. A., Fehsenfeld, F. C., Goldan, P. D., Herwehe, J., Hübler, G., Kuster, W. C., Martin, R., McMillen, R. T., Montzka, S. A., Norton, R. B., Parrish, D. D., Ridley, B. A., Shetter, R. E., Walega, J. G., Watkins, B. A., Westberg, H. H., and Williams, E. J.: Rural Oxidants in the Southern Environment (ROSE) program, J. Geophys. Res., 103, 22 491-22 508, 1998.

George, L. A., Hard, T. M., and O'Brien, R. J.: Measurement of free radicals $\mathrm{OH}$ and $\mathrm{HO}_{2}$ in Los Angeles smog, J. Geophys. Res., 104, 11 643-11 655, 1999.

Haggerstone, A.-L., Carpenter, L. J., Carslaw, N., and McFiggans, G.: Improved model predictions of $\mathrm{HO}_{2}$ with gas to particle mass transfer rates calculated using aerosol number size distributions, J. Geophys. Res., 110, D04303, doi:10.1029/2004JD005282, 2005.

Harrison, R. M., Yin, J., Tilling, R. M., Cai, X., Seakins, P. W., Hopkins, J. R., Lansley, D. L., Lewis, A. C., Hunter, M. C., Heard, D. E., Carpenter, L. J., Creasey, D. J., Lee, J. D., Pilling, M. J., Carslaw, N., Emmerson, K. M., Redington, A., Derwent, R. G., Ryall, D., Mills, G., and Penkett, S. A.: Measurement and modelling of air pollution and atmospheric chemistry in the U.K. west midlands conurbation: overview of the puma consortium project, Sci. Tot. Env., 360, 5-25, 2006.

Heard, D. E., Carpenter, L. J., Creasey, D. J., Hopkins, J. R., Lee, J. D., Lewis, A. C., Pilling, M. J., Seakins, P. W., Carslaw, N., and Emmerson, K. M.: High levels of the hydroxyl radical in the winter urban troposphere, Geophys. Res. Lett., 31, L18112, doi:10.1029/2004GL020544, 2004.

Heard, D. E., and Pilling, M. J.: Measurement of $\mathrm{OH}$ and $\mathrm{HO}_{2}$ in the troposphere, Chem. Reviews. 103, 5163-5198, 2003.

Holland, F., Hofzumahaus, A., Schäfer, H.-J., Kraus, A., and Pätz,
H.-W.: Measurements of $\mathrm{OH}$ and $\mathrm{HO}_{2}$ radical concentrations and photolysis frequencies during BERLIOZ, J. Geophys. Res., 108, doi:10.1029/2001JD001393, 2003.

Hopkins, J. R., Lewis, A. C., and Read, K. A.: A Two-column method for long-term monitoring of Non-methane hydrocarbons (NMHC) and oxygenated volatile organic compounds (OVOCs), J. Env. Monitor., 5, 8-13, 2002.

Hough, A. M.: The calculation of photolysis rates for use in global tropospheric modelling studies, AERE Rep. R-13259, Her Majesty's Stn. Off., Norwich, England, 1988.

IUPAC.: Summary of evaluated kinetic and photochemical data for atmospheric chemistry, IUPAC Subcommittee for Gas Kinetic Data Evaluation, 2005.

Jenkin, M. E., Saunders, S. M., and Pilling, M. J.: The tropospheric degradation of volatile organic compounds: A protocol for mechanism development, Atmos. Env., 31, 81-104, 1997.

Jenkin, M. E., Saunders, S. M., Wagner, V., and Pilling, M. J.: Protocol for the development of the Master Chemical Mechanism, MCM v3 (Part B): Tropospheric degradation of aromatic volatile organic compounds, Atmos. Chem. Phys., 3, 181-193, 2003, http://www.atmos-chem-phys.net/3/181/2003/.

Konrad, S., Schmitz, Th., Buers, H.-J., Houben, N., Mannschreck, K., Mihelcic, D., Müsgen, P., Pätz, H.-W., Holland, F., Hofzumahaus, A., Schäfer, H.-J., Schröder, S., and Volz-Thomas, A.: Hydrocarbon measurements at Pabstthum during the BERLIOZ campaign and modelling of free radicals, J. Geophys. Res., 108, DOI:10.1029/2001JD000866, 2003.

Kurtenbach, R., Becker, K. H., Gomes, J. A. G., Kleffmann, J., Lorzer, J. C., Spittler, M., Wiesen, P., Ackermann, R., Geyer, A., and Platt, U.: Investigations of emissions and heterogeneous formation of HONO in a road traffic tunnel, Atmos. Env., 35, 3385-3394, 2001.

Lee, J. L., Lewis, A. C., Monks P. S., et al.: Ozone photochemistry during the UK heatwave of August 2003, Atmos. Env., 40, 7598 7613, 2006.

Lewis, A. C., Carslaw, N., Marriott, P. J., Kinghorn, R. M., Morrison, P., Lee, A. L., Bartle, K. D., and Pilling, M. J.: A larger pool of ozone-forming carbon compounds in urban atmospheres, Nature, 405, 778-781, 2000

Martinez, M., Harder, H., Kovacs, T. A., et al.: $\mathrm{OH}$ and $\mathrm{HO}_{2}$ concentrations, sources, and loss rates during the Southern Oxidants Study in Nashville, Tennessee, summer 1999, J. Geophys. Res., 108, doi:10.1029/2003JD003551, 2003.

Mihelcic, D., Holland, F., Hofzumahaus, A., Hoppe, L., Konrad, S., Müsgen, P., Pätz, H.-W., Schäfer, H.-J., Schmitz, T., VolzThomas, A., Bächmann, Schlomski, S., Platt, U., Geyer, A., Alicke, B., and Moortgat, G. K.: Peroxy radicals during BERLIOZ at Pabstthum: Measurements, radical budgets and ozone production, J. Geophys. Res., 108, doi:10.1029/2001JD001014, 2003.

Monks, P. S.: Gas-phase radical chemistry in the troposphere, Chem. Soc. Rev., 34, 376-395, 2005.

Monks, P. S., Rickard, A. R., Hall, A. L., and Richards, N. A. D. Attenuation of spectral actinic flux and photolysis frequencies at the surface through homogeneous cloud fields, J. Geophys. Res., 109, 17 206, 2004

Morita, A., Kanaya, Y., and Francisco, J. S.: Uptake of the $\mathrm{HO}_{2}$ radical by water: Molecular dynamics calculations and their implications for atmospheric modelling, J. Geophys. Res., 109, Art. No. D09201, 2004. 
Paulson, S. E., Chung, M., Sen, A. D., and Orzechowska, G.: Measurement of $\mathrm{OH}$ radical formation from the reaction of ozone with several biogenic alkenes, J. Geophys. Res. 103, $25533-$ 25 539, 1998.

Ren, X., Brune, W. H., Mao, J., Mitchell, M. J., Lesher, R. L., Simpas, J. B., Metcalf, A. R., Schwab, J. J., Li, Y., Demerjian, K. L., Felton, H. D., Boynton, G., Adams, A., Perry, J., He, Y., Zhou, X., and Hou, J.: Behaviour of $\mathrm{OH}$ and $\mathrm{HO}_{2}$ in the winter atmosphere in New York City, Atmos. Env. 40, supplement 2, 252-263, 2006.

Ren, X., Brune, W. H., Cantrell, C. A., Edwards, G. D., Shirley, T., Metcalf, A. R., and Lesher, R. L.: Hydroxyl and peroxy radical chemistry in a rural area of central Pennsylvania: Observations and model comparisons, J. Atmos. Chem., 52, 231-257, 2005.

Ren, X., Harder, H., Martinez, M., Lesher, R. L., Oliger, A., Simpas, J. B., Brune, W. H., Schwab, J. J., Demerjian, K. L., He, Y., Zhou, X., and Gao, $\mathrm{H} .: \mathrm{OH}$ and $\mathrm{HO}_{2}$ chemistry in the urban atmosphere of New York City, Atmos. Env., 37, 3639-3651, 2003.

Salisbury, G., Rickard, A. R., Monks, P. S., Allan, B. J., Baugitte, S., Penkett, S. A., Carslaw, N., Lewis, A. C., Creasey, D. J., Heard, D. E., Jaobs, P. J., and Lee, J. D.: Production of peroxy radicals at night via reactions of ozone and the nitrate radical in the marine boundary layer, J. Geophys. Res., 106, 12 669-12 687, 2001.

Saunders, S. M., Jenkin, M. E., Derwent, R. G., and Pilling, M. J.: Protocol for the development of the Master Chemical Mechanism, MCM v3 (Part A): Tropospheric degradation of nonaromatic volatile organic compounds, Atmos. Chem. Phys., 3, 161-180, 2003,

http://www.atmos-chem-phys.net/3/161/2003/.

Saylor, R. D.: An estimate of the potential significance of heterogenous loss to aerosols as an additional sink for hydroperoxy radicals in the troposphere, Atmos. Environ., 31, 3653-3658, 1997.

Shirley, T. R., Brune, W. H., Ren, X., Mao, J., Lesher, R., Cardenas, B., Volkamer, R., Molina, L. T., Molina, M. J., Lamb, B., Velasco, E., Jobson, T., and Alexander, M.: Atmospheric oxidation in the Mexico City metropolitan area (MCMA) during April 2003, Atmos. Chem. Phys. Discuss., 5, 6041-6076, 2005, http://www.atmos-chem-phys-discuss.net/5/6041/2005/.

Sillman, S.: The relation between ozone, $\mathrm{NO}_{x}$ and hydrocarbons in urban and polluted rural environments, Atmos. Env., 33, 18211845. 1999.

Smith, S. C., Lee, J. D., Bloss, W. J., Johnson, G. P., and Heard, D. E.: Concentration of $\mathrm{OH}$ and $\mathrm{HO}_{2}$ during NAMBLEX: Measurements and Steady State analysis, Atmos. Chem. Phys., 5, $12403-$ $12464,2005$.
Sommariva, R., Bloss, W. J., Brough, N., Carslaw, N., Flynn, M., Haggerstone, A.-L. Heard, D. E., Hopkins, J. R., Lee, J. D., Lewis, A. C., McFiggins, G., Monks, P.S Penkett, S.A., Pilling, M.J., Plane, J.M.C., Read, K.A., Saiz-Lopez, A., Rickard A. R., and Williams P. I: $\mathrm{OH}$ and $\mathrm{HO}_{2}$ chemistry during NAMBLEX: roles of oxygenates, halogen oxides and heterogeneous uptake, Atmos. Chem. Phys.,, 6, 1135-1153, 2006.

Sommariva, R., Haggerstone, A.-L., Carpenter, L. J., Carslaw, N., Creasey, D. J., Heard, D. E., Lee, J. D., Lewis, A. C., Pilling, M. J., and Zádor, J.: $\mathrm{OH}$ and $\mathrm{HO}_{2}$ chemistry in clean marine air during SOAPEX-2, Atmos. Chem. Phys., 4, 839-856, 2004, http://www.atmos-chem-phys.net/4/839/2004/.

Stedman, J. R.: The predicted number of air pollution related deaths in the UK during the August 2003 heatwave, Atmos. Env., 38, 1087-1090, 2004.

Stevens, P. S., Mather, J. H., Brune, W. H., Eisele, F., Tanner, D., Jefferson, A., Cantrell, C., Shetter, R., Sewall, S., Fried, A., Henry, B., Williams, E., Baumann, K., Glodan, P., and Kuster, W.: $\mathrm{HO}_{2} / \mathrm{OH}$ and $\mathrm{RO}_{2} / \mathrm{HO}_{2}$ ratios during the Tropospheric $\mathrm{OH}$ Photochemistry Experiment: Measurement and theory, J. Geophys. Res., 102, 6379-6391, 1997.

Stockwell, W. R., Kirchner, F., and Kuhn, M.: A new mechanism for regional atmospheric chemistry modelling, J. Geophys. Res., 102, 25 847-25 879, 1997.

Tan, D., Faloona, I., Simpas, J. B., Brune, W., Shepson, P. B., Couch, T. L., Sumner, A. L., Carroll, M. A., Thornberry, T., Apel, E., Riemer, D., and Stockwell, W.: HOx budgets in a deciduous forest: results from the prophet summer campaign. J. Geophys. Res., 106, 24 407-24 427, 2001.

Thornton, J. and Abbat, J. P. D.: Measurements of $\mathrm{HO}_{2}$ uptake to aqueous aerosol: Mass accommodation coefficients and net reactive loss, J. Geophys. Res., 110, Art. No. D08309, 2005.

Thornton, J. A., Wooldridge, P. J., Cohen, R. C., Martinez, M., Harder H., Brune, W. H., Williams, E. J., Roberts, J. M., Fehsenfeld, F. C., Hall, S. R., Shetter, R. E., Wert, B. P., and Fried, A.: Ozone production rates as a function of NOx abundances and HOx production rates in the Nashville urban plume, JGR, 107, NO. D12, 4146, 10.1029/2001JD000932, 2002.

Volz-Thomas, A., Pätz, H.-W., Houben, N., Konrad, S., Mihelcic, D., Klupfel, T., and Perner, D.: Inorganic trace gases and peroxy radicals during BERLIOZ at Pabstthum: An investigation of the photostationary state of $\mathrm{NO}_{\mathrm{x}}$ and $\mathrm{O}_{3}$, J. Geophys. Res., 108, doi:10.1029/2001JD001255, 2003 . 